\title{
Role of neurotrophin signalling in the differentiation of neurons from dorsal root ganglia and sympathetic ganglia
}

\author{
Uwe Ernsberger
}

Received: 10 December 2008 / Accepted: 12 February 2009/Published online: 23 April 2009

(C) The Author(s) 2009. This article is published with open access at Springerlink.com

\begin{abstract}
Manipulation of neurotrophin (NT) signalling by administration or depletion of NTs, by transgenic overexpression or by deletion of genes coding for NTs and their receptors has demonstrated the importance of NT signalling for the survival and differentiation of neurons in sympathetic and dorsal root ganglia (DRG). Combination with mutation of the proapoptotic Bax gene allows the separation of survival and differentiation effects. These studies together with cell culture analysis suggest that NT signalling directly regulates the differentiation of neuron subpopulations and their integration into neural networks. The high-affinity NT receptors trkA, trkB and trkC are restricted to subpopulations of mature neurons, whereas their expression at early developmental stages largely overlaps. trkC is expressed throughout sympathetic ganglia and DRG early after ganglion formation but becomes restricted to small neuron subpopulations during embryogenesis when trkA is turned on. The temporal relationship between trkA and trkC expression is conserved between sympathetic ganglia and DRG. In DRG, NGF signalling is required not only for survival, but also for the differentiation of nociceptors. Expression of neuropeptides calcitonin gene-related peptide and substance $\mathrm{P}$, which specify
\end{abstract}

U.E. is supported by the DFG (Er145-4) and the Gemeinnützige Hertie-Stiftung.

\footnotetext{
U. Ernsberger

Interdisciplinary Center for Neurosciences (IZN), INF 307,

University of Heidelberg,

69120 Heidelberg, Germany

U. Ernsberger ( $\square)$

Max Planck Institute for Brain Research,

Deutschordenstrasse 46,

60528 Frankfurt, Germany

e-mail: uwe.ernsberger@urz.uni-heidelberg.de
}

peptidergic nociceptors, depends on nerve growth factor (NGF) signalling. ret expression indicative of nonpeptidergic nociceptors is also promoted by the NGFsignalling pathway. Regulation of TRP channels by NGF signalling might specify the temperature sensitivity of afferent neurons embryonically. The manipulation of NGF levels "tunes" heat sensitivity in nociceptors at postnatal and adult stages. Brain-derived neurotrophic factor signalling is required for subpopulations of DRG neurons that are not fully characterized; it affects mechanical sensitivity in slowly adapting, low-threshold mechanoreceptors and might involve the regulation of $\mathrm{DEG} / \mathrm{ENaC}$ ion channels. NT3 signalling is required for the generation and survival of various DRG neuron classes, in particular proprioceptors. Its importance for peripheral projections and central connectivity of proprioceptors demonstrates the significance of NT signalling for integrating responsive neurons in neural networks. The molecular targets of NT3 signalling in proprioceptor differentiation remain to be characterized. In sympathetic ganglia, NGF signalling regulates dendritic development and axonal projections. Its role in the specification of other neuronal properties is less well analysed. In vitro analysis suggests the involvement of NT signalling in the choice between the noradrenergic and cholinergic transmitter phenotype, in the expression of various classes of ion channels and for target connectivity. In vivo analysis is required to show the degree to which NT signalling regulates these sympathetic neuron properties in developing embryos and postnatally.

Keywords Neurotrophin - Sympathetic ganglia - Dorsal root ganglia $\cdot$ Development $\cdot$ Neurotrophin receptors
Abbreviations
ASIC acid-sensitive ion channel 


\begin{tabular}{|c|c|}
\hline Bax & bcl-2-associated pro-apoptotic protein \\
\hline BDNF & brain-derived neurotrophic factor \\
\hline ChAT & choline acetyltransferase \\
\hline CGRP & calcitonin gene-related peptide \\
\hline $\mathrm{DBH}$ & dopamine beta-hydroxylase \\
\hline DDC & 3,4-dioxyphenylalanine decarboxylase \\
\hline DRG & dorsal root ganglion \\
\hline $\mathrm{E}$ & embryonic day \\
\hline GFL & $\begin{array}{l}\text { glial-cell-line-derived neurotrophic factor family } \\
\text { of ligands }\end{array}$ \\
\hline HTMR & high-threshold mechanoreceptor \\
\hline $\mathrm{IHC}$ & immunohistochemistry \\
\hline $\mathrm{I}_{\mathrm{K}(\mathrm{Ca})}$ & calcium-dependent potassium current \\
\hline ISH & in situ hybridization \\
\hline LTMR & low-threshold mechanoreceptor \\
\hline $\mathrm{Na}_{\mathrm{v}}$ & sodium-dependent voltage channel \\
\hline NET & noradrenalin transporter \\
\hline $\mathrm{NF}$ & neurofilament \\
\hline NGF & nerve growth factor \\
\hline NT3 & neurotrophin 3 \\
\hline NT4 & neurotrophin 4 \\
\hline $\mathrm{P}$ & postnatal day \\
\hline PCNA & proliferating nuclear cell antigen \\
\hline PGP9.5 & neuron-specific protein gene product 9.5 \\
\hline PPT & preprotachykinin \\
\hline ret & "rearranged during transfection" proto-oncogene \\
\hline RT- & polymerase chain reaction on template \\
\hline PCR & synthesized by reverse transcription \\
\hline SAM & slowly adapting mechanoreceptor \\
\hline SCG & superior cervical ganglion \\
\hline SP & substance $\mathrm{P}$ \\
\hline STG & stellate ganglion \\
\hline $\mathrm{TH}$ & tyrosine hydroxylase \\
\hline TTX & tetrodotoxin \\
\hline TTXR & tetrodotoxin-resistant \\
\hline trk & $\begin{array}{l}\text { tyrosine kinase receptor, high-affinity } \\
\text { neurotrophin receptor }\end{array}$ \\
\hline TRP & $\begin{array}{l}\text { transient receptor potential family of cation } \\
\text { channels }\end{array}$ \\
\hline VAChT & vesicular acetylcholine transporter \\
\hline VIP & vasoactive intestinal peptide \\
\hline
\end{tabular}

\section{Introduction}

In 1951, a mouse sarcoma was reported that massively affects development of the peripheral nervous system when implanted in chick embryos (Levi-Montalcini and Hamburger 1951). This observation initiated a research effort that has demonstrated the involvement of nerve growth factor (NGF), the neurotrophic activity produced by the mouse sarcoma, and the other members of the neurotrophin (NT) family in the development of various populations of peripheral autonomic and sensory neurons. NGF administration and depletion studies in vivo have uncovered profound effects on the survival of neurons from dorsal root ganglia (DRG) and sympathetic ganglia (for a review, see Johnson et al. 1986), a function confirmed and extended to the related NTs, viz. brain-derived neurotrophic factor (BDNF) and NT3, by analysis in mutant mice (for a review, see Snider 1994). In addition to the survival effects of NTs, other aspects of neuronal development are affected by these growth factors. The promotion of neurite outgrowth may be the most prominent of these actions. In addition, the regulation of functional properties in various neuron populations became apparent when the hyperalgesic effect of NGF administration with a concomitant alteration in the sensitivity of certain DRG neuron populations (Lewin et al. 1993; Lewin and Mendell 1994) and the NGF-induced regulation of tyrosine hydroxylase $(\mathrm{TH})$ and dopamine $\beta$-hydroxylase (DBH) activity in sympathetic neurons (Thoenen et al. 1971; Angeletti et al. 1972) were observed in postnatal rats. The analysis of the differentiation effects of NTs has been compromised, however, by their requirement for neuron survival, in particular at embryonic stages, when function-specifying genes become expressed in specific populations of sensory and sympathetic neurons (see below; for a review, see Ernsberger 2008). Combining mutation of the proapoptotic Bax gene (for bcl-2 associated pro-apoptotic protein) with the mutational inactivation of NT or of NT receptor genes, however, prevents the loss of these neurons by cell death and allows the analysis of the differentiation effects exerted by NTs on these neuron populations during embryogenesis (Patel et al. 2000, 2003; Luo et al. 2007). In combination with cell culture analysis, the double-mutant analysis indicates that NT signalling directly regulates the specification of peripheral neuronal subtypes.

In this review, I shall discuss the effects elicited by the manipulation of NT signalling in vivo via the administration and the antibody-mediated depletion of NTs and via the mutation of the genes coding for NTs and their highaffinity tyrosine kinase receptors (trkA, trkB and trkC). In addition, the relevant tissue culture experiments are considered, as they demonstrate whether NTs directly affect DRG and sympathetic ganglion cells instead of promoting neurite outgrowth and access to other growth factors.

\section{Developmental expression of genes specifying neuronal diversity}

Neuronal genes in sympathetic and DRG become expressed during embryonic development and the equipment of the different neuron populations with population-specific gene products commences during the second embryonic week to 
become refined to neuron subpopulations in the third embryonic week of chick, rat and mouse development (for a review, see Ernsberger 2008). Genes might be expressed initially throughout the ganglion to become confined to defined subpopulations with ongoing development by the "progressive restriction" of expression, such as genes from the cholinergic gene locus in sympathetic ganglia (for a review, see Ernsberger 2008). Alternatively, they might become detectable in an increasing number of neurons because of a "progressive increase" in expression, such as the genes encoding the neuropeptides calcitonin generelated peptide (CGRP) and substance $P$ (SP) in DRG neurons (see below). In both cases, a population-restricted expression pattern is achieved during embryogenesis; this pattern for the neuropeptides, but not for the cholinergic locus, appears to be the mature pattern. Both expression modes are observed for the developmental expression profile of high-affinity NT receptors as detailed below.

\section{High-affinity NT receptors}

trkA and trkC, the high-affinity receptors for NGF and NT3, respectively (for reviews, see Klein 1994; Dechant et al. 1994; Barbacid 1994), show a developmental expression profile with remarkable similarities between sympathetic and DRG. Whereas trkC appears to be expressed throughout the ganglia at early developmental stages and becomes downregulated in a progressive restriction mode to a small neuron population at birth, trkA is initially undetectable and then becomes upregulated in a progressive increased mode of expression in the vast majority (DRG) or apparently all (sympathetic ganglia) neurons. For trkB, the high-affinity receptor for BDNF, its expression in DRG and sympathetic ganglia appears restricted from the outset.

\section{trkA and trkC NT receptors are prominently expressed during sympathetic neuron development}

In situ hybridization (ISH) in adult rat shows that neurons in both prevertebral and paravertebral sympathetic ganglia express predominantly trkA mRNA (Wetmore and Olson 1995; Schmidt et al. 1998). All neurons in rat superior cervical ganglia (SCG) strongly express trkA and 14\% express trkC mRNA (Wetmore and Olson 1995; Table 1). Likewise, in adult human paravertebral sympathetic gan- glia, all sympathetic neurons are reported to display trkA immunoreactivity, with $10 \%$ being immunoreactive for trkC (Garcia-Suarez et al. 1996). The observation of strong trkC immunoreactivity in the majority of sympathetic neurons of neonatal and adult rats (Zhou et al. 1997) is at variance with mRNA expression data in rat and mice and immunohistochemical analysis in humans and thus needs further examination. No immunoreactivity has been revealed for trkB in human ganglia (Garcia-Suarez et al. 1996) and a few $(<5 \%)$ of the neurons in rat SCG express trkB mRNA but at low levels (Wetmore and Olson 1995).

\section{trkC expression precedes trkA in rodent sympathetic ganglia}

Expression of trkA and trkC during sympathetic ganglion development was initially studied in rat embryos (Ernfors et al. 1992; Birren et al. 1993; DiCicco-Bloom et al. 1993). Early expression of trkC is found at embryonic day 13 (E13) by ISH as low and diffuse labelling (Ernfors et al. 1992). During the following few days, trkC mRNA can be detected by ISH (Ernfors et al. 1992; Birren et al. 1993) and Northern blot (DiCicco-Bloom et al. 1993). After E17.5, trkC mRNA decreases sharply (Birren et al. 1993) such that expression at birth is reduced by an order of magnitude (DiCicco-Bloom et al. 1993). Inversely, trkA is not detectable at E13 (Ernfors et al. 1992) or E14.5 (Birren et al. 1993) by ISH. At E16, however, most cells express low levels of trkA mRNA and intense labelling is detected at E18 (Ernfors et al. 1992). Northern blot analysis shows a 40-fold increase in trkA levels between E15.5 and birth (DiCicco-Bloom et al. 1993). A further increase in trkA levels occurring in rats postnatally has been detected with polymerase chain reaction on template synthesized by reverse transcription (RT-PCR; Ehrhard and Otten 1994).

In mouse, trkA transcripts in developing SCG are first detected at E13.5 by ISH (Fagan et al. 1996). Expression levels are increased at E15.5 and strong expression is detectable in newborn animals. trkC transcripts are detected as early as E11.5 in the sympathetic chain. At E13.5, they can be observed throughout the newly formed SCG (Fagan et al. 1996). With ongoing embryonic development, trkC expression levels decrease and become restricted to a small number of cells at postnatal day 0 (P0). Most of the transcripts are reported to correspond to signalling isoforms
Table 1 trk expression in adult mammalian sympathetic ganglia (IHC immunohistochemistry, ISH in situ hybridization)

\begin{tabular}{llllll}
\hline Species & Method & \multicolumn{2}{l}{ Percentage of positive cells } & & \multirow{2}{*}{ Reference } \\
\cline { 3 - 5 } & & trkA & trkB & trkC & \\
\hline Rat & ISH & 97 & $<5$ & 19 & Wetmore and Olson 1995 \\
Human & IHC & all & None & 10 & \\
\hline
\end{tabular}


carrying the tyrosine kinase domain. By quantitative RTPCR, a decrease of mRNA levels by an order of magnitude is observed for the kinase-positive trkC isoform relative to Dglyceraldehyde-3-phosphate dehydrogenase in mouse SCG between E14 and E18 (Wyatt et al. 1999; Fig. 1). Moreover, mRNA levels for the kinase-negative trkC isoform are reduced by $\sim 70 \%$ during this time period (Wyatt et al. 1997), a decrease that is not NT3-dependent as it also occurs in NT3 mutant animals (Wyatt et al. 1999). Likewise trkA induction is NT3-independent as it occurs in NT3 mutants (Wyatt et al. 1997) and trkC mutants (Fagan et al. 1996).

Expression of trkB is observed in embryonic sympathetic ganglia (Schecterson and Bothwell 1992). By E13 and E15, trkB-immunoreactive cells are detected coexpressing $\mathrm{TH}$ in mouse lumbar sympathetic ganglia (Straub et al. 2007). In 3-day-old to 4-week-old rats, trkB mRNA is barely detectable by RNA protection analysis in SCG,

\section{a}
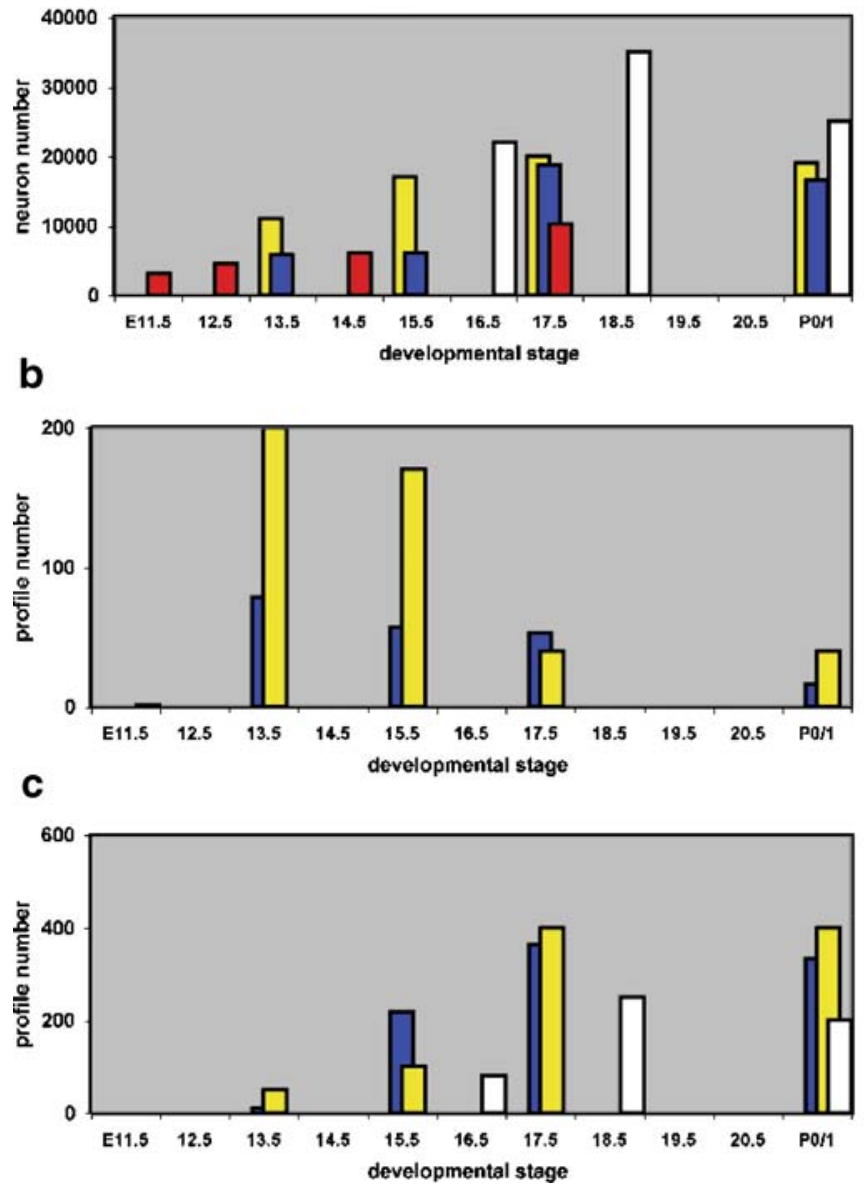

Fig. 1 Development of neuron number and trk expression in the superior cervical ganglion (SCG) of mouse embryos. a-c Number of neurons (a), mitotic profiles (b) and pycnotic profiles (c) in mouse SCG from embryonic day 11.5 (E11.5) to birth (P0/1). Data from ElShamy et al. 1996 (red bars), Fagan et al. 1996 (yellow bars), Wyatt et al. 1997 (white bars) and Francis et al. 1999 (blue bars). d Number although it occurs at low but distinct levels in prevertebral ganglia (Dixon and McKinnon 1994).

Thus, detectable trkC expression precedes that of trkA and is observed at E13 in rats and E11 in mice. Until birth, trkC expression is strongly downregulated such that small subpopulations are positive in postnatal mice, adult rats and humans. trkA is detectable at E16 in rats and E13 in mice and is expressed in the vast majority, or even in all neurons, during late embryogenesis and after birth. trkB expression during development has not been reported in detail.

\section{trkC expression precedes trkA in avian sympathetic ganglia}

trkC mRNA, as analysed by ISH, is detectable in primary sympathetic ganglia of the chick embryo at E4-E5 (Kahane and Kalcheim 1994). By E8, immunoreactivity is downregulated (Straub et al. 2007) and ISH staining of sections

\section{d}

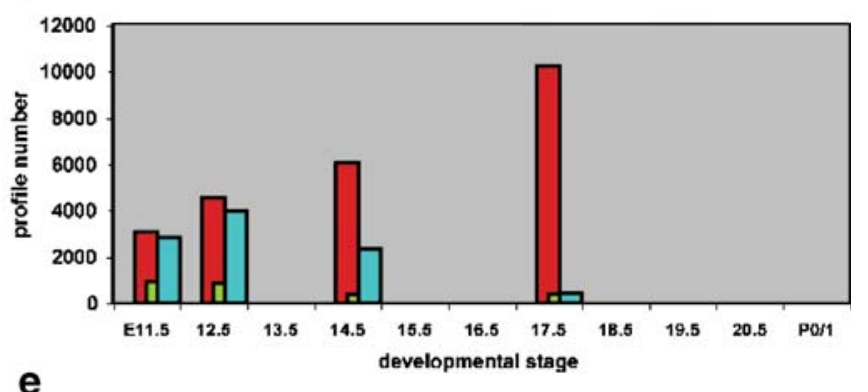

e
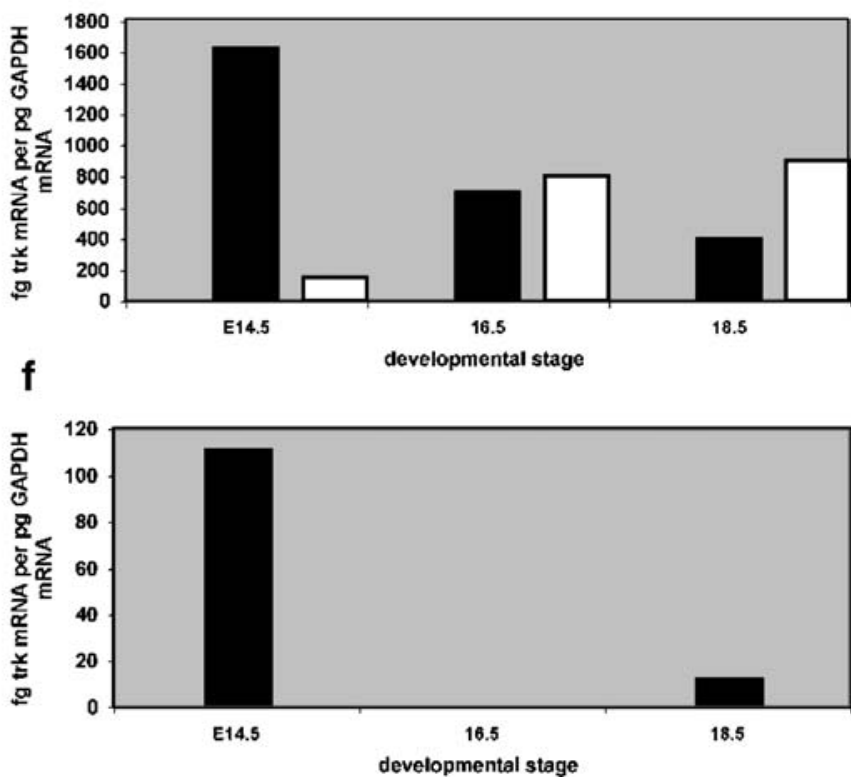

of neurons (red), TUNEL-positive profiles (green) and BrdUincorporating profiles (blue) in mouse SCG; from ElShamy et al. 1996. e, f Amount of mRNA for trkA (white bars) and the kinasenegative trkC isoform (black bars in e) and the kinase-positive trkC isoform (f) relative to D-glyceraldehyde-3-phosphate dehydrogenase $(G A P D H)$ mRNA. Data from Wyatt et al. 1997, 1999 
from secondary sympathetic ganglia is faint (Kahane and Kalcheim 1994), although the RT-PCR signal remains detectable, as shown in quail (Zhang et al. 1994). In contrast, trkA is readily detectable at E8 and, at E10, all neurons appear trkA-immunoreactive. trkB-expressing cells are not found by ISH between E4 and E14 (Dechant et al. 1993). trkB immunoreactivity, however, is observed transiently in embryonic sympathetic ganglia, being first detected at E5 and lost at E8 (Straub et al. 2007). At this stage, a larger fraction of neurons appears trkB-positive than trkA-positive and both coexpress trkC.

Thus, in chick sympathetic ganglia, trkC expression appears to precede trkA expression and becomes downregulated with ongoing development. trkA colocalizes with trkC during early stages of trkA expression and is detectable throughout the ganglion at later stages. Immunohistochemical data suggest early transient trkB expression in a large fraction of neurons also colocalizing with trkC. The discrepancy with ISH data for trkB needs clarification.

trkA and trkC expression patterns in sympathetic ganglia of chick embryos correlate with noradrenergic and cholinergic transmitter phenoptypes, respectively

In the paravertebral sympathetic ganglia of the chick embryo, the NT receptors trkA and trkC show inverse expression patterns (Brodski et al. 2002). At E12, the expression level for both receptors, as analysed by ISH, varies considerably between cells; cells expressing high levels for the mRNA of one receptor show low levels for that of the other. In addition, strong trkA expression overlaps with the noradrenalin transporter (NET), a marker for the noradrenergic transmitter phenotype. At E16, trkC immunoreactivity is absent from domains expressing the noradrenergic marker $\mathrm{TH}$ but is located in domains expressing the cholinergic marker choline acetyltransferase (ChAT; Brodski et al. 2000). At E18, trkA expression almost perfectly colocalizes with NET expression and negatively correlates with ChAT, as analysed by ISH (Brodski et al. 2002). Instead, ChAT expression colocalizes with trkC.

Data on the possible correlation of trkC expression with cholinergic properties in sympathetic ganglia of rodents are not available.

\section{High-affinity NT receptors trkA, trkB and trkC are expressed in subpopulations of DRG neurons}

Expression patterns for the high-affinity NT receptors of the trk family show restriction to distinct DRG neuron subpopulations in mature animals. In adult rodents and humans, approximately $40 \%$ of DRG neurons express trkA, the high-affinity NGF receptor (Table 2). Preferentially, small neurons are trkA-positive (Mu et al. 1993; McMahon et al. 1994) and 92\% of these cells coexpress CGRP in rat (Averill et al. 1995) indicating the nociceptive nature of this neuron subpopulation. Smaller populations, constituting approximately $20 \%$ of DRG neurons, express trkB and trkC, the high-affinity receptors for BDNF and NT3, respectively. Interestingly, the sum of trk-expressing neurons does not account for all DRG neurons in adult rodents; this is explained by a downregulation of trkA expression and replacement by c-ret expression in a subpopulation of the cells (see below).

\section{trkA is expressed in $80 \%$ of mouse DRG neurons during} the third embryonic week and their proportion drops to $40 \%$ postnatally

The developmental expression profile has been studied in detail for trkA in rodents (Fig. 2, Tables 2, 3). Detection of mRNA and protein by ISH and immunohistochemistry
Table 2 trk expression in mammalian DRG (IHC immunohistochemistry, ISH in situ hybridization)

\begin{tabular}{|c|c|c|c|c|c|}
\hline \multirow[t]{2}{*}{ Species, developmental stage } & \multirow[t]{2}{*}{ Method } & \multicolumn{3}{|c|}{ Percentage of positive cells } & \multirow[t]{2}{*}{ Reference } \\
\hline & & trkA & $\operatorname{trkB}$ & $\operatorname{trkC}$ & \\
\hline \multicolumn{6}{|l|}{ Development } \\
\hline Mouse, E11 & $\mathrm{IHC}$ & 20 & 40 & 70 & Farinas et al. 1998 \\
\hline Mouse, E13 & $\mathrm{IHC}$ & 80 & 8 & $<10$ & Farinas et al. 1998 \\
\hline Mouse, P0.5 & ISH & 90 & 8 & $28 / 8$ & Liebl et al. 1997, 2000 \\
\hline \multicolumn{6}{|l|}{ Adult mammals } \\
\hline Mouse & $\mathrm{IHC}$ & 41 & - & 9 & Orozco et al. 2001 \\
\hline Rat & $\mathrm{IHC}$ & $35-40$ & 5 & $15-20$ & Kashiba et al. 1996 \\
\hline Rat & ISH & 36 & 9 & 19 & Kashiba et al. 2003 \\
\hline Rat & ISH & 45 & 12 & 28 & Kobayashi et al. 2005 \\
\hline Rat & ISH & 45 & 26 & 21 & Wetmore and Olson 1995 \\
\hline Human & ISH & 46 & 29 & 24 & Josephson et al. 2001 \\
\hline
\end{tabular}



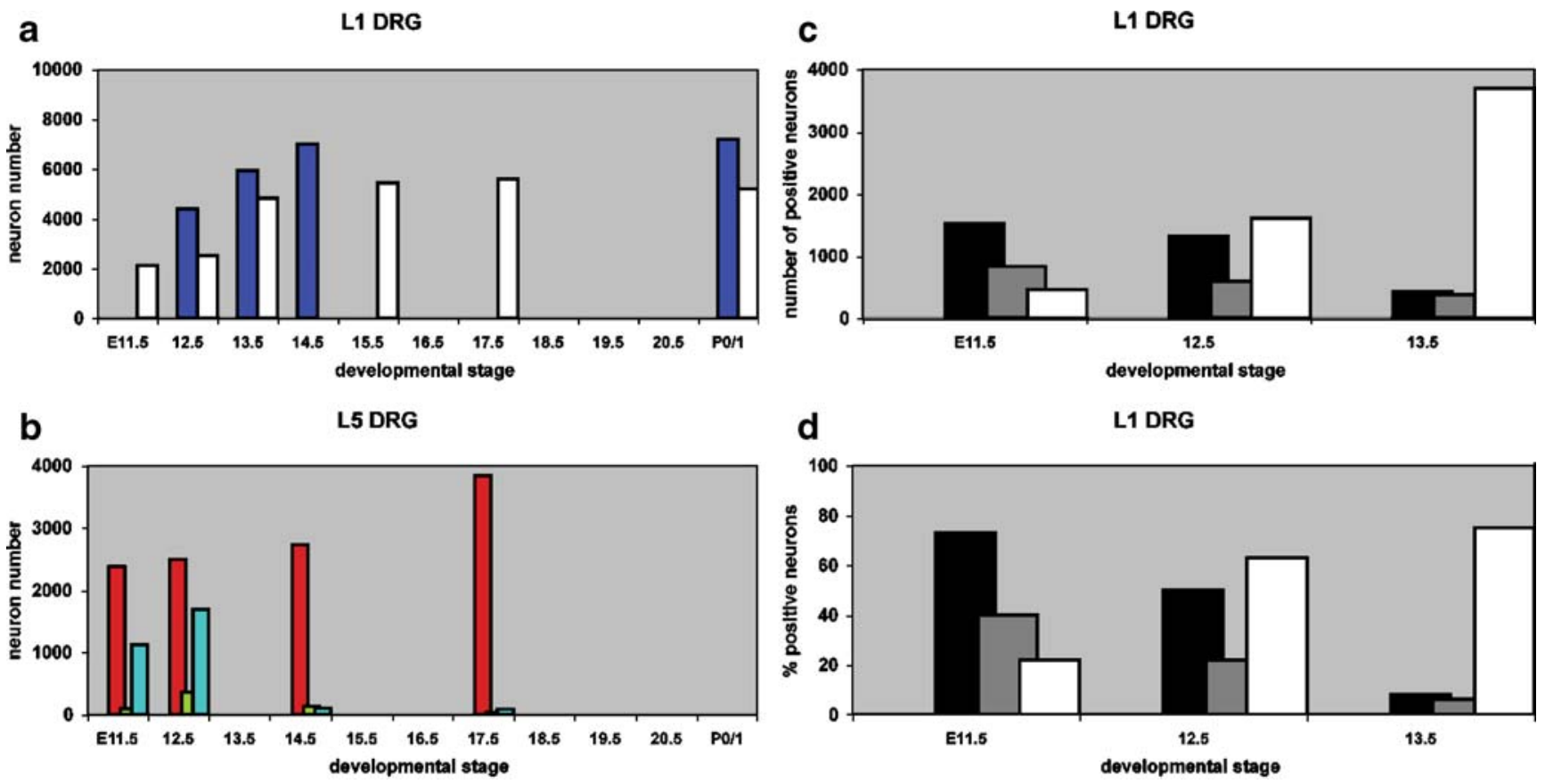

Fig. 2 Development of neuron number and trk expression in dorsal root ganglia (DRG) of mouse embryos. a Number of neurons in mouse L1 DRG from embryonic day 11.5 (E11.5) to birth (P0/1). Data from Farinas et al. 1996 (white bars), and Coppola et al. 2001 (blue bars). b Number of neurons (red), TUNEL-positive profiles (green)

(IHC) indicate an onset of expression in cervical and lumbar DRG of mouse embryos at E10.5 when expression levels are low and only a few positive cells are detectable (Phillips and Armanini 1996; White et al. 1996). A rapid increase in the number of trkA-positive cells occurs thereafter. As early as E11, 20\% of L1 DRG neurons express trkA immunoreactivity and their number increases dramatically over the next two days (Farinas et al. 1998). trkA-immunoreactive cells do not incorporate BrdU, have neuronal bipolar morphology and are immunoreactive for the neurofilament $150-\mathrm{kDa}$ subunit indicating that neurons, but not precursors, express the high-affinity NGF receptor (Farinas et al. 1998; White et al. 1996). Moreover, in chick embryos, no dividing cells are trkA-immunoreactive (Rifkin et al. 2000).

In mouse embryos, trkA-mRNA-positive cells amount to more than $50 \%$ of lumbar DRG cells at E11.5 (White et al. 1996). At E13, 80\% of DRG neurons are trkA-positive

and BrdU-incorporating profiles (blue) in mouse SCG; from ElShamy and Ernfors 1996. c, d Number and percentage, respectively, of L1 DRG neurons positive for trkA (white bars), trkB (grey bars) and trkC (black bars) at the embryonic stages indicated. Data from Farinas et al. 1998

(Farinas et al. 1998) and the same number is reported at E15 (White et al. 1996; Molliver and Snider 1997; Molliver et al. 1997). mRNA expression studies in rat embryos provide similar results (Ernfors et al. 1992; but see Mu et al. 1993) and protein detection describes the same $80 \%$ of neurons expressing trkA during the third week of rat embryonic development as analysed by IHC in L4/5 DRG (Benn et al. 2001). This high percentage of positive cells can still be detected in neonatal rats and mice (Table 3). Immunohistochemical studies in both species agree well thereby indicating a decrease in the proportion of trkA-positive cells to $60 \%$ of DRG neurons at P7 (Bennett et al. 1996a; Molliver and Snider 1997; Benn et al. 2001). Analysis in rat shows that adult percentages of trkA-immunoreactive cells of approximately $40 \%$ are reached during the third postnatal week. In mice, this value is reached as early as the second postnatal week (Luo et al. 2007).

Table 3 Postnatal trkA expression in mammalian DRG $(I H C$ immunohistochemistry)

\begin{tabular}{llllllll}
\hline \multirow{2}{*}{ Species } & Method & \multicolumn{3}{l}{ Percentage of positive cells } & & \multicolumn{2}{l}{ Reference } \\
\cline { 3 - 6 } & & P0-2 & P7 & P14/15 & P21 & Adult & \\
\hline Rat & IHC & 71 & 60 & 45 & - & - & Bennett et al. 1996a \\
& & 74 & - & - & - & 31 & Guo et al. 2001 \\
& & 79 & 60 & - & 45 & 42 & Benn et al. 2001 \\
Mouse & IHC & $\sim 80$ & 62 & 52 & - & 42 & Molliver and Snider 1997
\end{tabular}


trkB is expressed in a restricted population of DRG neurons

trkB-immunoreactive cells amount to $40 \%$ of thoracolumbar DRG neurons in E11 mice and do not incorporate BrdU (Farinas et al. 1998). At this stage, neurons are observed to coexpress $\operatorname{trkB}$ and $\operatorname{trkC}$ in addition to cells showing only trkB or trkC immunoreactivity. The incidence of $\operatorname{trkB} / \operatorname{trkC}$ double-positive neurons in lumbar DRG is $\sim 75 \%$ at E11.5, drops to $\sim 40 \%$ at $\mathrm{E} 12$ and to $\sim 10 \%$ at E12.5; by E14.5, no coexpression is detected (Kramer et al. 2006). The proportion of thoracolumbar DRG neurons in mice staining with trkB antibody is reduced to $\sim 8 \%$ at $\mathrm{E} 13$, the absolute number of trkBpositive cells at E13 amounting to approximately $50 \%$ of that at E11 (Farinas et al. 1998; Fig. 2).

trkB mRNA is detected by ISH in embryonic rats in a subset of DRG cells at E13 (Ernfors et al. 1992; Mu et al. 1993). Reported percentages in thoracolumbar DRG at E15 in rat and neonatally in rat and mice are close to $10 \%(\mathrm{Mu}$ et al. 1993; Liebl et al. 1997, 2000).

In thoracic DRG of adult rats, $10 \%$ of the neurons express trkB mRNA at high levels and an unquantified subset of neurons at low levels as detected by ISH (Wright and Snider 1995). In L4/5 DRG of adult rats, $26 \%$ of neurons express trkB mRNA (Wetmore and Olson 1995). Expression of the full-length tyrosine-kinase-containing trkB isoform is confined to neurons in the lumbar DRG, whereas truncated non-catalytic trkB isoforms are expressed in non-neuronal cells (McMahon et al. 1994; Wetmore and Olson 1995). Retrograde labelling from various nerves (see below) in adult rat indicates that trkB mRNA colocalizes with trkA in a subset of DRG neurons projecting to visceral nerves and with trkC in some neurons projecting to muscle (McMahon et al. 1994). Coexpression might be restricted to neurons expressing low trkB mRNA levels (for a discussion, see Snider and Silos-Santiago 1996).

trkC is expressed in almost all mouse DRG neurons at E11.5 and prevalence drops to less than $10 \%$ at E13

trkC immunoreactivity is detected in a few neurons of mouse thoracolumbar DRG at E10 and is widespread at E11 with approximately $70 \%$ of positive neurons (Farinas et al. 1998). In mouse cervical DRG, strong expression in the majority of cells is observed at E10.5 (Phillips and Armanini 1996). The onset of trkC expression in lumbar DRG precedes that of trkB by about half a day (Kramer et al. 2006). At E11.5, almost all cells in the lumbar DRG are intensely positive for trkC mRNA, as shown by ISH (White et al. 1996). Thereafter, mRNA expression is downregulated in lumbar and cervical DRG (White et al. 1996; Phillips and Armanini 1996). trkC-immunoreactive cells in mouse thoracolumbar DRG at E13 amount to less than $10 \%$ of the neuron population and the absolute number at this stage is reduced by $50 \%$ or more compared with that at E11 (Farinas et al. 1998; Fig. 2). In neonatal mice, less than $30 \%$ of neurons in L4 DRG are trkC-positive as detected by ISH (Liebl et al. 1997, 2000). The elevated postnatal values may be attributable to a later phase of trkC expression during the third embryonic week (Farinas et al. 1998).

In the lumbar DRG of adult rats, $21 \%$ of the neurons express trkC mRNA (Wetmore and Olson 1995). Expression patterns for trkC isoforms with and without the kinase domain are similar and restricted to neurons (McMahon et al. 1994).

trkC is expressed in mitotically active cells of chick DRG

None of the trkC-immunoreactive cells in mouse thoracolumbar DRG are reported to incorporate BrdU and cells show neuronal bipolar morphology and neurofilament 150$\mathrm{kDa}$ immunoreactivity suggesting that trkC protein is expressed in postmitotic neurons and not in mitotically active precursors (Farinas et al. 1998). In chick embryo DRG at brachial levels, however, trkC immunoreactivity is coexpressed with markers of neuronal progenitors and postmitotic neurons (Rifkin et al. 2000). Of the cells in the interior region of DRG from E4 chick, judged to be dividing by structural criteria, 20\% are trkC-positive. This has been confirmed by BrdU labelling and staining for phosphorylated histone H3. The reason for the discrepancy between mouse and chick is not clear. trkC mRNA as detected by ISH is found in neural crest cells of both species (Tessarollo et al. 1993; Kahane and Kalcheim 1994) and NT3, the high-affinity ligand for trkC, is a mitogen for cultured neural crest cells of quail (Kalcheim et al. 1992).

trkC is expressed early and coexpressed with trkA and trkB at the onset of their expression in DRG of avian embryos

trkC mRNA is found in chick embryos by ISH even in migrating neural crest (Kahane and Kalcheim 1994) and immunoreactivity is clearly detectable in mitotically active precursors (Rifkin et al. 2000). trkC mRNA has been shown in avian DRG while the ganglia are in the process of forming (Zhang et al. 1994; Rifkin et al. 2000). Strong and uniform trkC expression throughout the DRG lasts until E6 when expression becomes heterogeneous (Zhang et al. 1994; Kahane and Kalcheim 1994; Rifkin et al. 2000). At E3.5-E5, $\sim 85 \%$ of the cells immunoreactive for the neuronal marker $\mathrm{Hu}$ are trkC-positive in quail DRG (Zhang et al. 1994) and $63 \%$ of all cells are reported to be trkCimmunoreactive in chick DRG (Rifkin et al. 2000). At E6, this value has dropped to $28 \%$ and increases again to $48 \%$ at E15 in quail (Zhang et al. 1994). 
trkA-immunoreactive cells are detected only occasionally in DRG of E3 chick (Rifkin et al. 2000). At E4.5, 23\% of the nascent DRG cells are trkA-positive. trkA mRNA expression is detectable later by ISH in quail embryos and remains consistently at $73 \%$ of Hu-positive cells from E6 to E15, the last stage analysed in the study of Zhang et al. (1994).

trkB expression in chick DRG begins at E3; by E4.5, $47 \%$ of the nascent DRG cells are trkB-immunoreactive (Rifkin et al. 2000). At early stages (E3.5), 100\% of trkAand trkB-immunoreactive cells coexpress trkC. trk-positive subpopulations only begin to segregate at E6.

In summary, both the chick and mouse data show that trkC appears first, quickly followed by trkB, with trkA being the last trk turned on.

\section{trk expression in sensory neurons projecting to various target organs}

trk mRNA expression has also been studied in adult rat DRG neurons projecting to various target tissues after retrograde labelling by fluoro-gold applied to a varaiety of nerves (McMahon et al. 1994). Application to the sciatic nerve yields the same results as analysis of DRG neurons, independent of their target projection: 44\% trkA-positive, $27 \%$ trkB-positive and 17\% trkC-positive cells. Application to the cutaneous saphenous nerve gives similar results: $48 \%$ trkA-expressing, $16 \%$ trkB-expressing and $10 \%$ trkCexpressing cells. The picture is different for the lateral gastrocnemius nerve supplying skeletal muscle: 20\% trkApositive, $50 \%$ trkB-positive and 73\% trkC-positive cells. Again, the situation in the visceral pelvic nerve is different: $90 \%$ trkA-positive, 94\% trkB-positive and $2 \%$ trkCpositive cells. The data again support the concept of specific trk receptor expression in the different sensory neuron populations. In addition, they demonstrate that, in muscle and visceral sensory neurons, different trks must be coexpressed in adult rat.

trkA expression in innervating DRG neurons in the adult rat has been analysed by IHC after retrograde labelling by dye applied to two different target tissues, viz. skin and bladder (Bennett et al. 1996b): 43\% of cutaneous afferents are trkA-immunoreactive and $51 \%$ express the peptide CGRP. Of the visceral afferents, $75 \%$ are trkA-positive and 69\% express CGRP.

\section{Electrophysiological characterization shows that most, but not all, trkA-positive cells have nociceptor properties}

TrkA expression preferentially in nociceptive neurons was confirmed by the analysis of electrophysiologically characterized DRG neurons in rat (Fang et al. 2005). Intracellular recordings were performed on L3-L6 DRG neurons from young adult animals and sensory properties were deter- mined by mechanical and thermal stimulation of hindlimb and flank. Of neurons identified as nociceptors, 78\% were trkA-immunoreactive, $61 \%$ showing strong trkA signal and the remainder being weakly positive. Strong trkA signal was restricted to nociceptors. In the $\mathrm{C}$ fibre domain, $75 \%$ of nociceptive units expressed trkA: five out of eight analysed high-threshold mechanoreceptor (HTMR) units, two of two mechanocold receptors and one of two polymodal nociceptors are positive, whereas only one of three lowthreshold mechanoreceptors (LTMR), judged as non-nociceptive, expresses trkA. In the $\mathrm{A} \delta$ fibre domain, $93 \%$ of nociceptive units are trkA-positive and three out of five LTMR are positive. Of nociceptive units in the $A \alpha / \beta$ domain, 70\% express trkA: all HTMR but no LTMR with such conduction velocities are trkA-positive. In the same study, trkA expression in DRG neurons of various soma sizes has confirmed its preferential presence in small neurons: $75 \%$ of small cells, $58 \%$ of intermediate and $43 \%$ of large cells are trkA-positive (Fang et al. 2005). In this study, overall $70 \%$ of DRG neurons have been classified as trkA-positive including 37\% strongly positive cells and $33 \%$ weakly positive cells.

\section{Neuropeptide expression in DRG}

Immunhistochemical detection of the neuropeptide, SP, in a subset of DRG neurons (Hökfelt et al. 1975) marks the onset of a neurochemically based classification of sensory neurons. SP is expressed in $10 \%-40 \%$ of DRG neurons that are small to medium in diameter (for a review, see Lawson 2002). Upon electrophysiological characterization in the L6 and S1 DRG of guinea-pigs, all SP-immunoreactive neurons are nociceptors but not all nociceptors are SP-positive (Lawson et al. 1997; compare Leah et al. 1985). Of the cells in rat L4/ 5 DRG that express preprotachykinin (PPT) mRNA coding for SP, 78\% are also positive for trkA, as shown by ISH, whereas no overlap exists with trkB and trkC expression (Kashiba et al. 1996). During development, no SPimmunoreactive neurons are detected in rat DRG at E14.5, few positive cells are found at E19.5 and adult numbers are reached at birth (Hall et al. 1997; see also Marti et al. 1987).

Approximately $20 \%-50 \%$ of DRG neurons express the neuropeptide CGRP and these cells belong to all size classes (for a review, see Lawson 2002). Numbers vary with target tissue (Kashiba et al. 1991; Bennett et al. 1996b), segmental level (Ohtori et al. 2003) and even between different specimens within one species (Tonra and Mendell 1998). Electrophysiological characterization in the L6 and S1 DRG of guinea-pigs shows CGRP immunoreactivity in many but not all nociceptors (Lawson et al. 2002). In addition, some A fibre, but no $C$ fibre, mechanoreceptors with low threshold in the nonnociceptive range are CGRP-positive. Of cells expressing 
CGRP mRNA, 84\% are trkA-positive and $6 \%$ express trkC, whereas no coexpression is observed with trkB (Kashiba et al. 1996). The first appearance of CGRP-immunoreactive neurons in rat DRG is observed at E16 (Marti et al. 1987) and few neurons are CGRP-positive at E18.5 in rat (Hall et al. 1997) and E15 in mouse (Molliver and Snider 1997). Their proportion increases to approximately adult numbers after birth.

Thus, CGRP is expressed in DRG neurons of all size classes, whereas SP is restricted to small and mediumsized neurons. This observation is also reflected in the conduction velocity range of the respective neurons. As analysed in L4 DRG, SP-positive neurons belong to the C fibre and $\mathrm{A} \delta$ fibre classes, whereas CGRP-positive neurons belong to the $\mathrm{C}$ fibre, $\mathrm{A} \delta$ fibre and $A \alpha / \beta$ fibre classes (McCarthy and Lawson 1989, 1990). Consequently, SP is coexpressed in only a subpopulation of CGRPpositive neurons in cervical to lumbar DRG (Ju et al. 1987). Approximately $80 \%$ of CGRP or SP-positive cells express trkA. No coexpression is observed for $\mathrm{SP}$ and trkC, whereas a small proportion of CGRP-positive cells coexpresses trkC but not trkB.

\section{Ion channel expression in DRG}

Analysis of ion channel expression and its regulation by NTs has been performed in some detail in DRG neurons. Of particular interest are the transient receptor potential (TRP) family of ion channels that are involved in the transduction of sensory stimuli in DRG neurons. Their expression correlates in part with trk receptors and is reviewed in Ernsberger (2008). In addition, voltage-gated sodium channels are of interest because of their differential expression in DRG neuron subpopulations, their classification-relevant kinetic properties and their regulation by NTs.

The tetrodotoxin-resistant (TTXR) sodium channel Nav1.8/SNS/PN3 is expressed in $50 \%$ of $\mathrm{C}$ fibre and $10 \%$ of A fibre DRG neurons in adult rat (Tate et al. 1998; Amaya et al. 2000). It is essential for the perception of pain at cold temperatures (Zimmermann et al. 2007), although immunoreactivity is detected not only in nociceptors, but also in LTMR as analysed by electrophysiology and IHC of labelled L4-L6 neurons in rats (Djouhri et al. 2003). In A fibre, but not $\mathrm{C}$ fibre, nociceptors in rat L3-6 DRG, the intensities of immunoreactivity for Nav1.8 and trkA are correlated (Fang et al. 2005). The TTXR sodium channel Nav1.9/SNS2/NaN is selectively expressed in small DRG neurons (Tate et al. 1998) and is detected in nociceptive A and $\mathrm{C}$ fibre neurons as analysed by electrophysiology and IHC of labelled lumbar neuron in rats (Fang et al. 2002). In C fibre nociceptors of lumbar DRG, Nav1.9 immunoreactivity is correlated with isolectin-B4 (IB4)-binding levels (Fang et al. 2006).
Expression is detected in rat L4/5 DRG by IHC at E15 for Nav1.8 and not before E17 for Nav1.9 (Benn et al. 2001). At E17, Nav1.8 is detected in $25 \%$ of $\mathrm{DRG}$ neurons, mainly trkA-positive cells. Approximately $80 \%$ of trkA-immunoreactive cells are Nav1.8-positive at this stage. The proportion of trkA-positive cells that also expresses Nav1.8 decreases to $\sim 60 \%$ at P7 and to $\sim 40 \%$ in adult animals. A similar proportion binds IB4 in adult animals, whereas only $\sim 10 \%$ of IB4-binding neurons are Nav1.8positive at E17. Approximately $50 \%$ of total cell profiles are Nav1.8-immunoreactive from P7 to adulthood. The proportion of trkA-immunoreactive and IB4-binding neurons positive for Nav1.9 ranges between $40 \%-50 \%$ and $60 \%-70 \%$, respectively, in postnatal L $4 / 5$ DRG.

\section{Generation of diverse expression profiles during embryogenesis}

Developmental regulation of gene expression during embryogenesis occurs along fundamentally different pathways (Ernsberger 2008). The initial widespread or ubiquitous expression of trkC throughout the cell population in DRG and sympathetic ganglia becomes restricted between E11 and E13 in mouse DRG and, after E13, in SCG to small neuron subpopulations. In contrast, trkA expression, which commences after trkC expression, increases progressively during the second embryonic week in SCG and between E10 and E13 in DRG, such that virtually all (SCG) or the vast majority (DRG) of neurons are positive at birth.

A progressive increase in expression has also been observed for SP and CGRP in mouse DRG after induction during the third week of embryonic development. For SP, the adult complement of rat DRG neurons expressing the peptide appears present at birth, whereas for CGRP, the number of positive neurons continues to increase postnatally. Postnatal regulation, albeit as a decrease in the proportion of positive cells, is observed for trkA in DRG, where the proportion of cells expressing the high-affinity NGF receptor drops by $\sim 50 \%$. With regard to the voltagegated sodium channel Nav1.8, for which detailed counts are available during rat development, the adult complement of positive cells appears to be established at birth.

The available data show that induction of the expression of genes coding for the various neuronal differentiation markers occurs embryonically (Table 4, compare Table 2 in Ernsberger 2008) and that population-specific expression can be established during embryogenesis by a progressive restriction from an initially widespread expression or by a progressive increase in the number of positive cells. For certain markers such as SP, Nav1.8 and trkB, the adult complement of positive DRG neurons appears to be established at birth. For others, the prominent regulation 
Table 4 Onset of expression of receptors and function-specific markers $(><$ onset of expression between the indicated time points, $<$ onset not precisely shown but positive cells found at the time indicated). Expression analysed by in situ hybridization $(I S H)$ or immunohistochemistry $(I H C)$

\begin{tabular}{|c|c|c|}
\hline Marker & Rat (method) & Mouse (method) \\
\hline \multicolumn{3}{|c|}{ Dorsal root ganglia } \\
\hline $\operatorname{trkA}$ & - & E10.5 (ISH/IHC) ${ }^{\mathrm{a}}$ \\
\hline $\operatorname{trkB}$ & - & $<$ E11 $(\mathrm{IHC})^{\mathrm{b}}$ \\
\hline $\operatorname{trkC}$ & - & $<$ E10 $(\mathrm{IHC})^{\mathrm{b}}$ \\
\hline SP & E14.5 $><19.5(\mathrm{IHC})^{\mathrm{c}}$ & - \\
\hline CGRP & E16 $(\mathrm{IHC})^{\mathrm{c}}$ & $<$ E15 (IHC) \\
\hline Nav1.8 & $<$ E15 (IHC) & - \\
\hline Nav1.9 & Not before E17 (IHC) & - \\
\hline \multicolumn{3}{|c|}{ Sympathetic ganglia } \\
\hline $\operatorname{trkA}$ & E14.5><E16 (ISH) & E13.5 (ISH) \\
\hline $\operatorname{trkC}$ & $<$ E13 (ISH) ${ }^{\mathrm{b}}$ & $<$ E11.5 (ISH) ${ }^{\mathrm{b}}$ \\
\hline
\end{tabular}

${ }^{a}$ Partial postnatal downregulation

${ }^{\mathrm{b}}$ Initially widely expressed, embryonic downregulation to neuronal subpopulation

${ }^{\mathrm{c}}$ Adult numbers reached at birth

of the size of the positive cell population occurs postnatally. The postnatal loss of trkA expression in a significant number of DRG neurons depends on ret signalling (Luo et al. 2007). In sympathetic neurons, the massive postnatal increase in the proportion of cholinergic neurons depends on gp130 signalling (Stanke et al. 2006). Both events are transdifferentiation processes in existing cell populations, independent of proliferation or cell death.

\section{Comparison of expression patterns for NT receptors and receptors for the glial-cell-line-derived neurotrophic factor family of ligands}

Both the receptors for NTs (this review) and for the glial-cell-line-derived neurotrophic factor family of ligands (GFL; for a review, see Ernsberger 2008) are expressed in subpopulations of sympathetic and DRG neurons. This raises the question as to whether receptor expression delineates developmental stages and pathways possibly conserved between sympathetic and DRG neurons.

The developmental expression pattern of trkA and trkC receptors in rodents shows remarkable similarities between both neuron populations. In DRG and sympathetic ganglia, an initially widespread trkC expression yields to expression in small subpopulations at birth. With a delay, trkA becomes expressed in an increasing proportion of neurons in both classes of ganglia. Unlike adult sympathetic ganglia in which all neurons appear trkA-positive, only $40 \%$ of adult DRG neurons express trkA because of postnatal downregulation from $80 \%$ of trkA-positive cells in newborn animals. The situation is less clear for trkB for which ISH and IHC data for sympathetic ganglia are not in agreement.

ret, the signal transducing subunit of the GFL receptor complex, is detectable in mouse DRG and sympathetic ganglia at E11.5. Whereas expression occurs throughout the sympathetic ganglia at this stage, expression in DRG is initially limited to a few large neurons and appears in small DRG neurons only at later stages. Thus, widespread ret expression in mouse SCG appears to precede the trkA expression that commences at E13.5, whereas in mouse DRG, $80 \%$ of neurons are trkA-positive at E15 when only $10 \%$ of the neurons express ret. Therefore, ret expression appears to precede trkA expression in the bulk of sympathetic neurons, whereas the opposite holds true for the majority of DRG neurons. Even though the analysis of the developmental expression pattern of the receptor alpha subunits, GFRalphas, is incomplete, the data strongly suggest that the sequential appearance of NT and GFL signalling does not define a developmental progression conserved between sympathetic and DRG neurons.

\section{Role of NTs and their high-affinity receptors in DRG neuron development}

The massive effect of mouse sarcoma-derived neurotrophic activity, later characterized as NGF, on the peripheral nervous system of chick embryos included an increase in DRG cell numbers by $20 \%-50 \%$ (Levi-Montalcini and Hamburger 1951). Transgenic overexpression of NGF in the skin reproduced the dramatic effect of growth factor supply on neurite outgrowth (Albers et al. 1994) and DRG neuron counts (Mendelson et al. 1996). Experiments increasing NGF levels are nicely complemented by depletion studies with antibody injection or autoimmunization (for reviews, see Johnson et al. 1986; Snider 1994). These studies suggest a survival effect on nociceptive DRG neurons, an effect that is prominent during embryogenesis and lost rapidly after birth. Analysis of mice mutant for NGF and its high-affinity receptor trkA has confirmed the requirement of this signalling pathway for the survival of small and intermediate DRG neurons, including peptidergic and non-peptidergic nociceptors, but sparing large trkBand trkC-positive cells (for reviews, see Snider 1994; Snider and Silos-Santiago 1996). In addition, mutant mice have allowed the precise characterization of the timing of the survival requirement for trkA signalling and, in combination with mutation of the proapoptotic Bax gene, the analysis of neurite outgrowth and differentiation effects. 
Mutational inactivation of NGF and trkA genes shows their role in survival and neurite outgrowth during embryogenesis

In homozygous $\mathrm{NGF}$ and trkA mutant mice analysed during the first two postnatal weeks, DRG neuron number is reduced by $70 \%-90 \%$, with small neurons being preferentially affected (Crowley et al. 1994; Smeyne et al. 1994; Patel et al. 2000). Nociception is compromised in these animals. Whereas trkA-positive cells are lacking in NGF mutants, these animals show no apparent effect on the trkB- and trkC-positive neuron population (Crowley et al. 1994).

In both NGF and trkA mutant mice, increased apoptosis can be observed at E13.5 (White et al. 1996). No obvious difference from the wildtype is found at E11.5 and the apoptosis level at E15.5 is even lower in trkA mutants than in wildtype animals. With increased apoptosis, ganglion areas become dramatically reduced and neuron counts performed at E17.5 show a 79\% loss in cell numbers in L4/L5 DRG. This deficit in cell number is maintained and shows that NGF plays a crucial role for survival between E11.5 and E15.5. In mice in which both trkA and Bax have been mutated, cell loss is eliminated (Patel et al. 2000) and cell numbers in the L4 DRG of newborn mice are $160 \%$ that of the wildtype in contrast to the $90 \%$ loss in trkA mutants. Moreover, in NGF/Bax double-mutants, cell loss is also eliminated and ganglion size is comparable with that of the wildtype.

Cell loss affects preferentially small neurons in NGF (Crowley et al. 1994) and trkA (Smeyne et al. 1994; Silos-Santiago et al. 1995) mutant mice. In the dorsal root, more than $95 \%$ of unmyelinated axons are lost and the number of myelinated axons is reduced by $50 \%$ in trkA mutants, including the majority of $A \delta$ axons (Silos-Santiago et al. 1995). As shown by DiI labelling, the vast majority of the dorsal root projection to laminae I and II in the dorsal horn of the spinal cord is eliminated in trkA mutant mice. In contrast, Ia afferent fibres projecting to the ventral horn of the spinal cord are not affected by trkA mutation (Liebl et al. 1997). The data demonstrate that NGF signalling is crucial for nociceptor but not proprioceptor development. Since projection is rescued in Bax mutants and as trkA-immunoreactive fibres are found in the superficial dorsal horn of NGF/Bax double-mutants similar to wildtype (Patel et al. 2000), the disrupted nociceptor projection to spinal cord target areas in NGF and trkA mutant mice appears secondary to cell death. As synapse formation has not been analysed, however, it remains unclear whether normal synaptic connectivity is rescued in the double-mutant animals. In the periphery, loss of fibres in trkA mutants has been shown in the cutaneous saphenous nerve and hindlimb skin by staining for
PGP9.5 (Patel et al. 2000). Importantly, this loss is not reversed in NGF/Bax double-mutants, demonstrating that NGF signalling is required for peripheral target innervation, independently of cell survival. Correspondingly, no trkApositive axons can be found in the distal hindlimb of NGF/ Bax double-mutants.

The data show an increased loss of neurons in the absence of NGF and trkA signalling at the end of the second embryonic week in mutant mice; this can be rescued by mutation of the Bax gene. Whereas the defects in the central projection of sensory neurons in mutant mice are compensated by rescue from cell death, the NGF requirement for neurite outgrowth to peripheral targets is independent of the survival effect and cannot be rescued by the Bax mutation.

trkA/Bax double-mutant mice show embryonic NGF requirement for neuropeptide induction

A specific requirement for NGF during the embryonic development of the SP-positive population of DRG neurons is apparent from NGF depletion studies. Anti-NGF antibody injection at E16.5 into rats results in a $86 \%$ decrease in SP-like immunoreactivity in DRG as analysed by radioimmunoassay at 4 months of age and depletion of SP as shown by IHC in lamina I and II of the spinal cord (Goedert et al. 1984; Ruit et al. 1992). Moreover, in adult animals, anti-NGF antibody injection leads to decreased SP protein (Shadiack et al. 2001). In addition, CGRP protein is decreased, whereas peptide and RNA for galanin and vasoactive intestinal peptide (VIP) are increased. This resembles the changes that are observed after the axotomy of sensory neurons (Verge et al. 1995; Shadiack et al. 2001) and that can be reduced by NGF infusion (Verge et al. 1995).

Expression of SP and CGRP is likewise compromised in DRG of NGF or trkA mutants. In NGF mutant mice, the immunoreactivity for both peptides is reduced in DRG (Crowley et al. 1994). Only a few cells weakly stained for CGRP can be detected in ganglia of 3-day-old mutant animals and immunoreactive axonal processes are completely absent in both the dorsal horn of the spinal cord and the hairy skin. Similarly, in trkA mutant animals, CGRP immunoreactivity in the dorsal horn is virtually eliminated and few if any positive DRG neurons are observed at P15 (Silos-Santiago et al. 1995). In DRG of newborn trkA mutant animals, CGRP is not detected by IHC (Patel et al. 2000; Moqrich et al. 2004) or ISH (Minichiello et al. 1995).

SP immunoreactivity is also eliminated at both stages (Silos-Santiago et al. 1995; Patel et al. 2000). ISH in neonatal animals has shown that SP mRNA expression is reduced in trkA mutant animals, although Minichiello et al. (1995) report $16 \%$ of positive cells remaining from $39 \%$ in 
wildtype animals, in contrast to Patel et al. 2000 who have reported the absence of SP mRNA.

The data show that NGF affects neuropeptide contents in embryonic DRG but they leave open whether this is simply attributable to its survival effect. In trkA/Bax doublemutants, peptide expression is not restored (Patel et al. 2000) indicating that NGF is required not only for survival, but also for differentiation. Since the Bax mutation does not rescue the peripheral innervation deficits, the NGF effects may be either direct or indirect via access to other targetderived signals.

Cell culture studies indicate that NGF directly affects neuropeptide expression. In DRG explant cultures from E13.5 Bax mutant mice in which DRG neurons do not require NGF for survival, NGF supplementation boosts the proportion of CGRP-immunoreactive cells after 3.5 days to $41 \%$ as compared with a few cells in untreated cultures (Patel et al. 2000). This establishes the ability of NGF to induce neuropeptide expression in the ganglion cell population independently of target access. As $80 \%$ of mouse DRG neurons express trkA even at E13, the question remains as to whether all trkA-positive cells can be induced to express CGRP after NGF treatment. In dissociated cultures from the DRG of E14.5 rat, prepared before CGRP immunoreactivity is detectable in vivo, supplementation with NGF, which is required for survival, does not result in the widespread expression of CGRP immunoreactivity (Ai et al. 1999). Only 14\% of neurons are CGRP-immunoreactive after 8 days in NGF-treated cultures.

In a study of neurons differentiating from precursor cells of embryonic chick DRG, the percentage of SPimmunoreactive cells, surprisingly, does not differ in cultures treated with NGF or BDNF (Ernsberger and Rohrer 1988). This may reflect a peculiarity of avian DRG neurogenesis, since the vast majority of chick DRG neurons are SP-immunoreactive early during embryogenesis (Duc et al. 1991).

Taken together, the studies show that NGF is required for the development of the normal complement of SP- and CGRP-positive DRG neurons. In vitro, NGF can directly induce neuropeptide expression in mouse DRG neurons at embryonic stages.

NGF/Bax double-mutant mice show NGF requirement for development of small-diameter ret-positive DRG neurons

In addition to peptidergic nociceptors, DRG contain a population of small-diameter nociceptors that do not express the neuropeptides SP and CGRP. Instead, these neurons express the receptor tyrosine kinase ret (for a review, see Ernsberger 2008). Small-diameter DRG neurons expressing ret are generated from trkA-positive cells during the third week of mouse embryogenesis and, to a large extent, lose trkA expression postnatally. Analysis in NGF/ Bax double-mutant mice demonstrates that these cells require NGF not only for survival, but also for ret expression (Luo et al. 2007). In newborn animals, ret mRNA levels in small DRG neurons as detected by ISH are greatly reduced and the proportion of positive cells is decreased from $62 \%$ to $31 \%$. In addition, mRNA for the receptor alpha subunit GFRalphal is completely absent from mutant DRG and the proportion of GFRalpha2positive cells is decreased from $18 \%$ to $9 \%$. The percentage of GFRalpha3-positive cells is unaltered (35\%). In cultures from DRG neurons, NGF increases the expression of mRNAs for ret, GFRalpha1 and GFRalpha2, but not for GFRalpha3, as analysed by RT-PCR (Luo et al. 2007).

The data show that NGF signalling is not only required for the differentiation of peptidergic nociceptors, but is also necessary for the normal expression of ret, the marker and signalling component of nonpeptidergic nociceptors. The culture experiments indicate that NGF acts directly rather than by promoting neurite outgrowth and access to other growth factors.

NGF is involved in embryonic regulation of TRP channel expression

The TRP channel family contains thermosensitive and chemosensitive ion channels involved in the transduction of the respective stimuli in sensory neurons (for reviews, see Jordt et al. 2003; Dhaka et al. 2006). In DRG, they are expressed in subpopulations and overlap with trkA expression (for a review, see Ernsberger 2008). The heat- and capsaicin-sensitive TRPV1 channel is expressed in $\sim 50 \%$ of trkA-positive cells in adult rat DRG and $\sim 50 \%$ of TRPV1positive cells express trkA. The cold- and menthol-sensitive TRPM8 channel is expressed in $\sim 40 \%$ of trkA-positive cells and virtually all TRPM8-positive cells express trkA (Kobayashi et al. 2005).

Expression of both channels in DRG neurons is compromised by the lack of NGF signalling. ISH on DRG from newborn NGF/Bax double-mutant mice reveals a reduction in the number of TRPV1-mRNA-expressing cells by $\sim 30 \%$ and of TRPM8-mRNA-expressing cells by more than $80 \%$ (Luo et al. 2007). The data show that NGF signalling is required for the embryonic development of the normal complement of TRPV1- and TRPM8-expressing cells.

NGF affects $\mathrm{A} \delta$ and $\mathrm{C}$ fibre sensitivities postnatally

NGF administration and depletion in vivo affects the receptive properties of $\mathrm{C}$ fibre and $\mathrm{A} \delta$ fibre DRG neurons and demonstrates an important role of NGF for postnatal 
development of nociceptive afferents (for a review, see Lewin and Mendell 1993). In rats that received NGF injections for the first two postnatal weeks, mechanical thresholds of A $\delta$ HTMR recorded from L5 dorsal roots are reduced compared with controls when recorded between 5 and 7 weeks of age (Lewin et al. 1992, 1993). At 1013 weeks, the effect has disappeared indicating that NGF injection in newborn rats leads to a lasting, but not permanent, alteration in A $\delta$ nociceptors. $\mathrm{C}$ fibre nociceptors from animals injected with NGF on P2-P14 and analysed at the adult stage show increased heat sensitivity such that $60 \%$ can be classified as mechanosensitive and heatsensitive units (C-MH) in contrast to $30 \%$ in control animals in which the majority of units is only mechanosensitive (C-M; Lewin and Mendell 1994). This change is still observed in 4-month-old animals.

After the injection of anti-NGF antibodies into rats from P2 to P14, DRG cell counts do not differ significantly from control indicating that requirement for NGF for survival is lost rapidly postnatally (Lewin et al. 1992). However, abundance of A $\delta$ HTMR recorded from L5 dorsal root and driven by sural nerve stimulation decreases to $16 \%$ as compared to control $41-49 \%$ (Lewin et al. 1992; Lewin and Mendell 1994). In addition, the mechanical thresholds of A $\delta$ HTMR increase. In parallel to the loss of A $\delta$ HTMR, abundance of D hair afferents increases from $29 \%$ to $51 \%$ (Lewin et al. 1992). The significance of the observation that $\mathrm{D}$ hairs might replace HTMR is still unclear and the authors suggest this to be attributable to a redirection of fibres to the dermis and signals therein in experimental animals.

The data show that mechanical sensitivity in A $\delta$ HTMR and heat sensitivity in $\mathrm{C}$ fibre nociceptors can be increased by NGF administration in postnatal animals. Experiments involving the injection of anti-NGF antibodies do not yet provide an answer to the question as to whether an NGF supply is required for the development of normal mechanical and heat sensitivity. Instead, they show an increase in abundance of D hair afferents at the expense of A $\delta$ HTMR. A molecular analysis of this effect might shed light on the lineage relationship between HTMR and LTMR.

NGF affects temperature but not mechanical sensitivity of $\mathrm{A} \delta$ and $\mathrm{C}$ fibre units in adult rats

NGF injection in juvenile (2-5 weeks old) or adult rats does not result in alterations of adaptation properties or mechanical thresholds of A $\delta$ HTMR, indicating that this phenotypic plasticity is restricted during development (Lewin et al. 1993). Heat sensitivity of $A \delta$ and $C$ fibre units, however, remains subject to regulation by NGF, even in adult animals. In a saphenous nerve/skin preparation from adult rats, perfusion of receptive fields from $\mathrm{A} \delta$ and $\mathrm{C}$ fibre units with NGF induces a significant increase in heat sensitvity without changing cold or mechanical sensitivity (Rueff and Mendell 1996). Upon NGF depletion by injection of trkAIgG into skin of adult rats, the proportion of nociceptors responding to heat in a sural nerve/skin preparation drops from $57 \%$ to $32 \%$ (Bennett et al. 1998). The percentage of nociceptors responding to noxious cold is unaltered, however. Thus, heat sensitivity in slowly conducting DRG afferents, unlike mechanical and cold sensitivity, appears to be NGF-sensitive throughout life in rats.

In vitro, NGF enhances the heat response of TRPV1positive small-diameter neurons from adult lumbar DRG within minutes of application (Galoyan et al. 2003). Because of the rapid onset of heat sensitization, the process must occur posttranslationally and several signalling pathways affecting TRPV1 activity have been characterized leading to TRPV1 phosphorylation and its insertion into the plasmamembrane (Zhang et al. 2005; Huang et al. 2006). Rapid sensitization is not observed in trkA-positive neurons from early postnatal animals (Zhu et al. 2004) indicating a developmental alteration in the regulation of heat sensitivity by NGF. In addition to posttranslational regulation, NGF might regulate TRPV1 mRNA levels. Over extended culture periods (3-10 days) of DRG neurons from adult rats, NGF can maintain higher numbers of TRPV1-mRNApositive and TRPV1-immunoreactive cells (Ogun-Muyiwa et al. 1999; Bron et al. 2003) and increase TRPV1 mRNA levels in comparison with controls as found by Northern Blot (Winston et al. 2001). NGF also prevents the decline in the number of cold-sensitive DRG neurons with time in culture as analysed via the cold-induced elevation of intracellular calcium concentration (Babes et al. 2004). NGF increases the proportion of menthol-sensitive coldresponsive neurons suggesting a regulation of TRPM8, the menthol-sensitive cold receptor.

These culture studies show that heat-sensitive TRP channels in adult DRG neurons can be regulated by NGF at the mRNA level and posttranslationally. They also suggest that cold-sensitive channels may, under certain conditions, be the target of NGF regulation.

NGF is involved in inflammation-induced plasticity of DRG neuron properties

NGF levels are increased in inflamed tissue and contribute to alterations in sensory neurons that convert exclusively noxious stimulus detectors to sensors for innocuous inputs (for reviews, see Lewin and Mendell 1993; Woolf 1996; Pezet and McMahon 2006; Woolf and Ma 2007). The alterations are attributable to early posttranslational changes and later transcription-dependent modulation of neuronal properties (for reviews, see Woolf and Costigan 1999; Woolf and Ma 2007), both of which change the basal 
sensitivity of nociceptors and elicit stimulus-evoked hypersensitivity.

Following inflammation induced by complete Freud's adjuvant (CFA) in the hindpaw of an adult rat, the number of PPT-mRNA-expressing neurons in L3/4 DRG triples within $48 \mathrm{~h}$ (Leslie et al. 1995). Anti-NGF antibody injection prevents the induction of PPT expression. In addition, CFAinduced inflammation induces the expression of the heat receptor TRPV1 within 1 day after application. Protein levels are increased as shown by Western blot and IHC (Ji et al. 2002; Amaya et al. 2004), whereas mRNA levels appear unaltered as shown by RNase protection (Ji et al. 2002). The increase in TRPV1 immunoreactivity is prevented by neutralizing NGF with anti-NGF antisera. Carrageenaninduced inflammation sensitizes nociceptors to heat, an effect blocked by NGF-neutralizing trkA-IgG (Koltzenburg et al. 1999). Expression of the cold receptor TRPA1, but not TRPM8, is increased after CFA-induced inflammation within 1 day as observed by RT-PCR and ISH for mRNA detection (Obata et al. 2005). Intrathecal administration of anti-NGF antiserum decreases this induction.

The above studies thus show that NGF as a mediator of inflammatory processes might alter gene expression patterns in adult DRG thereby modulating sensory neuron properties. Various mechanisms appear to be involved as protein levels can be increased independently of or in correlation with the induction of mRNA. In the case of the peptidergic nociceptors, this may lead to a massive yet transient alteration in apparent population size.

NGF affects expression of TTXR sodium conductances in DRG neurons

In addition to TRP ion channels, the expression of voltagegated sodium channels is affected by NGF. ISH and RTPCR analysis of adult rat DRG shows the differential expression of several sodium channel $\alpha$ subunit mRNAs suggesting a molecular basis for the biophysical heterogeneity of sodium currents in these cells (Black et al. 1996).

In vitro evidence has demonstrated that NGF influences sodium current expression and diversity in cultured adult rat DRG neurons (Omri and Meiri 1990). In particular, the percentage of cells with TTXR sodium conductances is increased by NGF (Aguayo and White 1992). NGF depletion in vivo by immunization decreases TTXR current density as analysed by whole-cell patch clamping in freshly dissociated IB4-negative neurons, which represent the subpopulation of trkA-positive nociceptors in adult rat (Fjell et al. 1999a). The changes are accompanied by decreases in the mRNA hybridization signal for the voltage-dependent sodium channel Nav1.8/SNS showing reduced expression in SNS-positive cells and a smaller proportion of positive cells.
NGF overexpression in mice from the K14 keratin promoter results in elevated Nav1.8/SNS mRNA expression levels and also affects other voltage-gated sodium channels (Fjell et al. 1999b). This study has not clarified whether the percentage of positive cells changes. In dissociated cultures of adult rat DRG neurons, Nav1.8/ SNS mRNA decreases with time and this decrease is attenuated by NGF (Black et al. 1997). A correlation between mRNA levels and the amplitude of TTXR peak currents has been found in some, but not all, studies (Fjell et al. 1999a; Dib-Hajj et al. 1998; but see Fjell et al. 1999b, 1999c).

These studies show that NGF regulates sodium channel mRNA levels and TTXR current density in adult neurons both in vivo and in vitro. Regulation during embryonic development and for other sodium channel subunits remains to be analysed.

Mutational inactivation of BDNF and trkB genes reveals their role in specification of slowly adapting mechanoreceptors

In BDNF mutant mice, $27 \%-36 \%$ of neuron loss has been reported in DRG of animals analysed between P0 and P16 (Ernfors et al. 1994a; Jones et al. 1994; Liebl et al. 2000; Agerman et al. 2003). During embryonic development, the cell loss becomes apparent at E12.5, when DRG cell number is reduced by $11 \%$ compared with that in the wildtype (Liebl et al. 2000). By E13.5, cell loss reaches $31 \%$, close to the $36 \%$ reported for newborn mutants in this study. Following mutation of the catalytic domain of trkB, similar cell losses have initially been reported in newborn animals (Klein et al. 1993; Minichiello et al. 1995). The variability between DRG at different axial levels is obvious, with a loss of neurons ranging from approximately $20 \%$ to $50 \%$ at L1-L4. A more recent study of trkB mutant mice from the same source has found no difference in neuron number between newborn mutant and wildtype animals; approximately $30 \%$ neuronal cell loss occurs in lumbar DRG only by the second postnatal week (Silos-Santiago et al. 1997). The reason for this discrepancy is not known.

The number and percentage of trkB-positive neurons is reduced in newborn BDNF mutant mice, albeit the cells have not disappeared completely (Liebl et al. 1997). Moreover, the number of trkC-positive cells is reduced, but not their proportion. In addition, $20 \%-30 \%$ of trkApositive cells are lost in newborn BDNF mutants, although their proportion is unaltered as compared with that of the wildtype (Liebl et al. 1997). No reduction in the number of SP- and CGRP-positive DRG neurons is detectable in neonatal animals mutant for BDNF (Liebl et al. 2000) or trkB (Minichiello et al. 1995). The data show that the trkA- 
positive neurons lost in BDNF mutant mice are not peptidergic nociceptors. Furthermore, proprioceptors appear to be unaffected, since the number of cells immunoreactive for parvalbumin, a marker for proprioceptive neurons, is not significantly decreased in newborn BDNF mutant animals (Liebl et al. 2000).

BDNF mutant animals show defects in movement coordination and balance (Ernfors et al. 1994a; Jones et al. 1994). Similarly, trkB mutant animals display orientation deficits in addition to disturbed feeding behaviour (Klein et al. 1993). The movement disturbances may be explained by massive cell loss in vestibular ganglia as reported in BDNF mutant mice (Jones et al 1994; Ernfors et al. 1994a).

In addition to the survival effects on sensory neurons, the analysis of mutants has provided evidence for the role of BDNF in the specification of slowly adapting mechanoreceptors (SAM), viz. DRG neurons that innervate Merkel cells in touch dome complexes. In an in vitro saphenous nerve/skin preparation, an increase in SAM mechanical threshold has been found in homozygous juvenile and heterozygous adult BDNF mutant animals (Carroll et al. 1998). Other afferents (rapidly adapting, D hair, AM) show normal properties and receptor prevalence is not altered. Since Merkel cell number and morphology are normal in touch domes of back skin and other receptor types also appear unaltered, a specific effect of BDNF on SAM properties must be assumed, rather than a general alteration in the mechanical properties of the surrounding tissue.

Acid-sensitive ion channel ASIC2/BNC1, a member of the Deg/ENaC superfamily of ion channels, is required for touch sensation in mice (Price et al. 2000). Its mutation leads to reduced mechanosensitivity of rapidly adapting mechanoreceptor and SAM units but not of $\mathrm{D}$ hair and $\mathrm{AM}$ receptors or $\mathrm{C}$ fibres. In DRG from adult heterozygous BDNF mutant mice, the amount of mRNA for ASIC2 is reduced by $20 \%-30 \%$ as compared with the wildtype (McIlwrath et al. 2005). Primary cultures from heterozygous animals exhibit reduced ASIC2 expression, as detected by IHC. The percentage of positive large and medium-sized neurons and the signal intensity in large neurons are significantly reduced in heterozygous BDNF mutants as compared with wildtype animals. The addition of BDNF to these cultures increases ASIC2 immunofluorescence in a transcription-dependent manner.

Even though the DRG neuron populations that are lost in BDNF mutant mice are not well defined, the importance of BDNF signalling for slowly adapting mechanoreceptive properties can be characterized in some detail. The control of $\mathrm{DEG} / \mathrm{ENaC}$ ion channel expression appears to play a role in this process.
NT4 mutation results in altered prevalence of trkBand trkC-expressing neurons and loss of $\mathrm{D}$ hair afferents

NT4, the last member of the NT family identified, can signal through trkB receptors but differs in its binding requirements to the receptor (Minichiello et al. 1998). Unlike BDNF mutation, mutational inactivation of NT4 does not lead to significant changes in DRG neuron counts at E13 (96\% of wildtype) and only to a small but significant increase (113\% of wildtype) in L4 ganglia of newborn mice (Liebl et al. 2000). At 2 months of age, counts drop (to $86 \%$ of wildtype), although no statistical significance is reported (Liu et al. 1995). Correspondingly, the lack of an increase in TUNEL staining provides no evidence for enhanced apoptosis at E11-E13 (Liebl et al. 2000), whereas in 8week-old animals, a small number of TUNEL-positive neurons is found in NT4 mutant animals but not in wildtype mice (Stucky et al. 2002a).

In the saphenous nerve of adult NT4 mutant mice, the number of myelinated axons is reduced by $16 \%-29 \%$, affecting particularly small myelinated fibres in the $\mathrm{A} \delta$ range (Stucky et al. 1998; Liebl et al. 2000). In contrast, myelinated axon number in tibial and peroneal nerve is increased by $19 \%$ and $18 \%$, respectively, suggesting an increase in proprioceptive units (Liebl et al. 2000). In parallel, the prevalence of trkB- and trkC-expressing neurons changes in adult DRG. The number of trkBpositive cells is reduced by $78 \%$ compared with that of the wildtype, a change reported to occur between 5 weeks of age and adulthood in one study (Stucky et al. 2002a). In another study, even in newborn mice, their proportion is reduced from $11 \%$ in wildtype to $1 \%$ in homozygous mutants, whereas the percentage of trkC-positive cells increases from $8 \%$ to $17 \%$ (Liebl et al. 2000). At the same time, an increase occurs in the number of parvalbuminimmunoreactive cells, but no reduction in CGRP- and SPpositive cells (Liebl et al. 2000), indicating an effect on proprioceptor but not nociceptor numbers.

An in vitro saphenous nerve/skin preparation shows an almost complete loss of D hair receptors in adult NT4 mutant mice (Stucky et al. 1998). Their proportion among A $\delta$ fibres decreases from $35 \%$ in the wildtype to $4 \%$ in homozygous mutants and the remaining units show atypical electrical and mechanical properties. In skin, the number of hair follicles encircled by myelinated fibres is reduced by $40 \%$. AM fibres in the A $\delta$ range show normal thresholds, slowly adapting fibres in the $\mathrm{A} \beta$ range display normal mechanical response and prevalence. $\mathrm{C}$ fibre mechanical and heat sensitivity is unaltered. The effect of the NT4 mutation on D hair receptors becomes apparent around the 7th postnatal week (Stucky et al. 2002a). Whereas myelinated axons are reduced as early as 5 weeks after birth, D hair receptor number appears unchanged at this 
time point, as shown by electrophysiological investigation. Other myelinated mechanoreceptors appear in normal numbers.

These studies demonstrate that NT4 acts as survival factor for a population of adult DRG neurons. In addition, they show an alteration in the prevalence of trkB- and trkCpositive neurons in newborn and adult mice. In parallel, the number of neurons expressing the proprioceptor marker parvalbumin is increased at birth.

NT3 mutation affects cell survival and the size of various afferent neuron populations early in DRG development

Mutational inactivation of NT3 leads to a massive neuronal deficit in DRG; a $60 \%-80 \%$ loss of cells is reported for newborn animals (Farinas et al. 1994; Tessarollo et al. 1997; Liebl et al. 1997, 2000; Coppola et al. 2001) and a 55\% loss for animals at P12-P16 (Ernfors et al. 1994b). The reduction in neuron numbers in newborn trkC mutant mice is distinctly smaller; a $17 \%-19 \%$ loss has been reported for animals with a mutation in the trkC tyrosine kinase domain (Klein et al. 1994; Minichiello et al. 1995; Silos-Santiago et al. 1997) and a 27\%-34\% loss for animals devoid of all trkC isoforms (Tessarollo et al. 1997; Coppola et al. 2001).

Cell loss in mutant DRG becomes apparent early during development. As early as E11.5 in NT3 mutant mice, significant loss of total cells as analysed by Nissl staining and loss of neurons as detected by IHC for neurofilament have been reported (Farinas et al. 1996). The reduction in cell number varies according to axial level and mouse line (Farinas et al. 1996; ElShamy and Ernfors 1996; Liebl et al. 1997, 2000). Neuron loss increases with ongoing development to reach $\sim 70 \%$ at $\mathrm{P} 0$. This is in stark contrast to trkC mutant animals in which neuron losses amount to $\sim 30 \%$ at P0, a value reached as early as E13.5-E14.5 (Liebl et al. 1997; Coppola et al. 2001). Whereas cell losses in NT3 and trkC mutant animals have been shown to have a similar time course until E13.5 in one study (Liebl et al. 1997), neuron losses in NT3 mutants in another study exceed those in trkC mutants even by E12.5 (Coppola et al. 2001).

Increased numbers of apoptotic cells have been observed in DRG of both NT3 and trkC mutant mice as early as E11.5 (White et al. 1996). At E13.5, their number in NT3 mutants exceeds that of trkC mutants. Quantification in NT3 mutant animals shows a four-fold to six-fold increase in TUNEL-positive cells and pyknotic profiles at E11 as compared with wildtype animals (ElShamy and Ernfors 1996; Farinas et al. 1996; ElShamy et al. 1998). At E12 and E14, numbers are still elevated, but only to $120 \%-150 \%$ of the wildtype value. BrdU labelling has demonstrated a deficit of proliferating cells in NT3 mutant cells even in E11 DRG, but no change in their proportion (ElShamy and
Ernfors 1996; Farinas et al. 1996). Analysis of the colocalization of TUNEL labelling with the differentiation markers neurofilament and peripherin as compared with the proliferation marker BrdU led to conflicting results. The detection of TUNEL labelling in the majority of BrdUpositive cells, the colocalization of the TUNEL label and cell-cycle S-phase proteins and the occurrence of TUNEL labelling in only a few peripherin-immunoreactive cells have led to the conclusion that NT3 inflicts constraints on the number of proliferating cells (ElShamy and Ernfors 1996; ElShamy et al. 1998). The absence of TUNEL and BrdU colocalization together with TUNEL and neurofilament colabelling in another study suggests that neuronal apoptosis is important (Farinas et al. 1996).

In NT3 mutant animals, trkC-positive neurons are partially depleted at E11.5 and have disappeared entirely at E12.5/E13.5 (Tessarollo et al. 1994; Farinas et al. 1998; Coppola et al. 2001). At those times when trkC immunoreactivity can be observed, it is mostly associated with pyknotic profiles; TUNEL-positive cells are often, but not always, stained with trkC antibodies (Farinas et al. 1998). At E15.5, the reappearance of trkC staining in NT3 mutants has been observed in a subset of DRG neurons (Farinas et al. 1998) and, in newborn mutant animals, a small subset of trkC-positive cells can be detected (Liebl et al. 1997). Apoptosis is also seen in trkB-positive neurons of NT3 mutant mice (Farinas et al. 1998). In contrast to trkCexpressing cells, however, numerous trkB-positive neurons appear morphologically normal. At E11, trkB-positive cells are reduced by $35 \%-40 \%$ in NT3 mutants. In newborn animals, the loss of trkB-positive cells is even larger, i.e. close to the reduction in total neuron counts of this study (79\%), and so the proportion of trkB-positive cells among total neurons barely changes (Liebl et al. 1997). trkAexpressing cells appear normal in NT3 mutant mice at E11 (Farinas et al. 1998). trkA immunoreactivity is not associated with pyknotic profiles and the number of trkApositive neurons is not reduced in E11 animals (Farinas et al. 1998). In newborn animals, however, the number but not proportion of trkA-positive cells is reduced (Liebl et al. 1997). Again, the neuron loss closely parallels the reduction in total neuron counts of this study (79\%) and so the proportion of trkA-positive cells among total neurons is unaltered (Liebl et al. 1997).

Whereas the number of SP- and CGRP-immunoreactive cells is not reduced in trkC mutant DRG (Minichiello et al. 1995), a $60 \%-65 \%$ loss of neurons immunoreactive for these peptides is observed in DRG from E18.5 NT3 mutant mice (Airaksinen and Meyer 1996). This loss is similar to the loss in total neuron number and suggests the lack of a specific effect on peptidergic nociceptors, but the presence of an effect on the transition of precursors to differentiating neurons. 
The large discrepancy between cell losses in NT3 and trkC mutant mice points to an action of NT3 via other trk receptors; this is supported by the survival effect of NT3 in cultures of trkC mutant neurons (Davies et al. 1995). Both trkA and trkB signalling might mediate non-trkC NT3 action (Davies et al. 1995; Farinas et al. 1998; Coppola et al. 2001).

NT3 is required for establishment of proprioceptor axon projections

NT3 and trkC mutant mice show severe movement disorders (Ernfors et al. 1994b; Tessarollo et al. 1994; Farinas et al. 1994; Klein et al. 1994; Tojo et al. 1995). The lack of muscle spindles and Golgi tendon organs has been described for NT3 mutant mice (Ernfors et al. 1994b; Farinas et al. 1994) and an absence of afferent contacts to muscle has been observed from the first stage (E15.5) onwards when they begin to develop in wildtype mice (Kucera et al. 1995). The specific requirement of NT3 for muscle proprioceptor development has also been demonstrated by the lack of parvalbumin immunoreactivity, a marker for proprioceptive neurons, in DRG, as analysed in postnatal mutants (Ernfors et al. 1994b; Airaksinen and Meyer 1996). Retrograde labelling of afferent projections to the spinal cord by DiI application has demonstrated the loss of group Ia afferents in postnatal mutant animals for NT3 (Ernfors et al. 1994b; Liebl et al. 1997) and trkC (Klein et al. 1994; Liebl et al. 1997). In NT3 mutant mice, developmental analysis has shown that projections from the axial and thigh muscle to ventral layers of the spinal cord are lacking as early as E13.5-E15.5 (Tessarollo et al. 1994, 1997; Kucera et al. 1995). In trkC mutant animals, group II afferents are also missing (Klein et al. 1994), whereas dorsal horn innervation appears grossly normal. In contrast to the disturbed proprioceptor projections, DiI application to dorsal roots shows a grossly normal central projection of cutaneous afferents in NT3 mutant mice (Tessarollo et al. 1994).

Combination of the NT3 mutation and Bax mutation dissociates survival from axon outgrowth defects in the NT signalling mutants. In Bax/NT3 double-mutant animals, loss of DRG neurons by apoptosis is prevented and neuron number in L4 ganglia of newborn animals is increased by $\sim 50 \%$ as compared with controls (Patel et al. 2003). Moreover, numerous neurons express parvalbumin even though they are smaller in diameter than in control animals. Despite the rescue in neuron number, axon counts in the soleus nerve of newborn Bax/NT3 double-mutant animals show a $64 \%$ decrease compared with controls and muscle spindles are absent from the soleus muscle. The absence of parvalbumin-positive fibres in hindlimb nerves even at E15 and E17 points to the disturbed peripheral projection of proprioceptors at early developmental stages.
Retrograde labelling by DiI applied to the DRG shows that central processes of proprioceptors are also affected in Bax/NT3 double-mutant animals (Patel et al. 2003). Proprioceptive axons stop in the intermediate zone of the spinal cord and fail to project to the motor neuron pool in the ventral spinal cord, as analysed at E15 and E17 and in newborn animals. This correlates with the absence of immunoreactivity for the transcription factor Er81 at E15 (Arber et al. 2000). Furthermore, the number of DRG neurons expressing Er81 mRNA is markedly reduced in E15 double-mutant animals. In NT3 mutant mice transgenically expressing NT3 in muscle under the control of the myogenin promoter, DRG cell survival and axonal projection to the ventral spinal cord are rescued (Wright et al. 1997). In addition, Er81 expression is rescued (Patel et al. 2003) indicating that peripheral NT3 sources suffice to maintain proprioceptor survival, to induce Er81 expression and to target central proprioceptor projections. In DRG explants cultured from E11.5 and E12.5 embryos, NT3 but not NGF rapidly (within $3 \mathrm{~h}$ ) induces the expression of Er81 immunoreactivity suggesting the direct regulation of this transcription factor by NT3 (Patel et al. 2003). Since ventral spinal cord projection and monosynaptic inputs from Ia afferents to motoneurons are restored in Er81 mutant mice transgenically expressing NT3 under the control of the myogenin promoter (Li et al. 2006), NT3 appears to act independently of Er81 on central proprioceptor targeting.

These studies show that NT3, in addition to its survival action on proprioceptors, is required for the formation of peripheral and central proprioceptor connections. The inhibition of axon collateral growth in the grey matter of embryonic rats after the systemic administration of NT3 (Zhang et al. 1994b) and the absence of central (and peripheral) Ia projections in newborn mice after transgenic overexpression of NT3 in the nervous system under the control of the nestin gene promoter and enhancer regions (Ringstedt et al. 1997) underlines the importance of the target muscle as a source of NT3 in the specification of proprioceptor connectivity.

NTs affect primary afferent connectivity in spinal cord

The NT3 requirement for proprioceptor axons to accomplish projection to the ventral horn of the spinal cord prompts the question as to whether NT3 also affects the synaptic connections to motoneurons. Embryonic overexpression of NT3 in muscle of transgenic mice under the control of a myosin light chain-1 promoter leads to a substantial increase of monosynaptic excitatory postsynaptic potential (EPSP) amplitudes recorded extracellularly from ventral roots in neonatal mice (Wang et al. 2007). Whereas the density of Ia projections to the ventral spinal 
cord appears unaltered, intracellular recordings from motoneurons show strong inputs from Ia afferents supplying unrelated muscles. Postnatal muscular NT3 administration does not cause these changes showing that embryonic target-derived NT3 affects the specificity of proprioceptor connectivity to motoneurons.

In mice with mutational inactivation of the zink finger transcription factor Egr3, monosynaptic EPSPs in motoneurons are severely reduced postnatally (Chen et al. 2002). Electrical stimulation of muscle nerves elicits EPSPs in motoneurons at P0; at P2, however, the evoked EPSPs are lost. Horseradish peroxidase (HRP) application to dorsal roots at $\mathrm{P} 8$ shows that afferent projections to the spinal cord and termination patterns appear normal. In addition, afferents are sensitive to mechanical stimulation in the muscle indicating that the network components are functional but that transmission is disturbed. NT3 injection into the hindlimb during the first postnatal week maintains functional sensory-motor connectivity (Chen et al. 2002). The results show that NT3 derived from peripheral targets can rescue synaptic transmission from proprioceptors to motoneurons in the ventral horn of the mutant spinal cord at postnatal stages.

The subcutaneous injection of NT3 on every other day during the first postnatal week increases the EPSP amplitude recorded on P8 intracellularly from antidromically identified motoneurons in rat (Seebach et al. 1999). Treatment with trkC-IgG decreases EPSP amplitude just below statistical significance suggesting that this should be re-examined by employing more effective suppression of NT3 signalling. NT3 application, either chronically (Arvanian et al. 2003) or acutely (Arvanian and Mendell 2001), to the rat spinal cord potentiates synaptic potentials elicited from dorsal roots. Thus, target-derived and centrally applied NT3 affects proprioceptor inputs to motoneurons. The mechanisms appear to differ between embryonic and postnatal animals.

Application of NGF with an osmotic minipump to muscle in adult rats for at least 15 days increases the number of functional $\mathrm{A}$ and $\mathrm{C}$ fibre inputs from gastrocnemius afferents to dorsal horn neurons (Lewin et al. 1992). Even a single NGF injection into the gastrocnemius soleus muscle increases the proportion of L4 dorsal horn neurons responding to stimulation from gastrocnemius soleus nerves with action potentials within 1 day from $5 \%$ to $28 \%$ (Hoheisel et al. 2007). The application of anti-NGF antiserum in rat from P2-P14 alters the response pattern of lamina I neurons (Lewin and Mendell 1996). Whereas $90 \%$ of the dorsal horn neurons in control animals are noxious-specific, only $45 \%$ behave noxious-specifically in anti-NGF antiserum-treated animals, 30\% show a wide dynamic range behaviour and $23 \%$ have no cutaneous receptive field. Thus, dorsal horn connectivity appears to be strongly affected by NGF signalling. Since A $\delta$ afferent populations are strongly altered by the anti-NGF antiserum treatment, it is unclear whether the change in dorsal horn excitability is attributable to anatomical or physiological alterations. Analysis of double-mutant mice deficient for Bax and NGF signalling may clarify this issue.

At adult stages, the excitabiltiy of spinal dorsal horn neurons is upregulated during inflammation in a NGFdependent manner (for reviews, see Thompson et al. 1999; McMahon and Jones 2004). The central sensitization is partially prevented by the antagonism of BDNF, which is expressed in an NGF-sensitive mode in small-diameter nociceptors and acts as a neuromodulator in the dorsal horn.

The data show that NTs alter spinal cord transmission of primary afferent impulses. Even though the cellular and molecular mechanisms remain to be analysed, the findings demonstrate that NTs crucially affect connectivity at the first central relay station of primary afferent neurons.

\section{Summary}

\section{trk expression}

The distribution of trkA, trkB and trkC and the patterns of neuron loss in the respective mutant animals demonstrate their expression and requirement for survival in wellsegregated populations of DRG neurons (for a review, see Snider 1994; Snider and Silos-Santiago 1996). Nociceptors depend on trkA, whereas proprioceptors require trkC signalling. The neuron populations depending on trkB signalling are less well described.

A correlation of trk expression and sensory targets has been performed in adult rats. trkA-positive units constitute the majority of trk-expressing DRG neurons innervating skin, whereas the bulk of neurons innervating muscle expresses trkC. trkB expression is found in a small proportion of DRG neurons in the cutaneous saphenous nerve and almost all of the DRG neurons projecting in the visceral pelvic nerve. Together with a high percentage of trkA-positive fibres in the pelvic nerve, this shows that trk receptors may be coexpressed in selected DRG neuron populations.

trkA-expressing DRG neurons in rat have been characterized electrophysiologically. The large majority $(\sim 80 \%)$ of skin nociceptors are trkA-positive. The detection of trkA in some apparently non-nociceptive LTMR with $\mathrm{A} \delta$ and $\mathrm{C}$ fibre conduction velocities shows, however, that trkA expression in DRG is not restricted to pain detectors.

The developmental profile of trk expression has been analysed in detail in mouse embryos. trkC expression is detectable early at E10 and, by E11, almost all cells are intensely trkC-positive. Thereafter, their number decreases, whereas total neuron number increases such that trkC- 
positive cells amount to less than $10 \%$ at E13. The first trkA-positive cells are reported at E10.5 in mouse DRG and their number and percentage increase thereafter. At E11, approximately $20 \%$ of neurons express trkA and, by E13, the proportion has increased to $80 \%$. Moreover, in the chick embryo, a similar succession for trk receptor expression is observed and the expression of trkC in mitotically active precursors has been shown. In addition, the coexpression of trk receptors during sensory neurogenesis has been quantified in chick embryos. Apparently all of the trkAor trkB-positive cells transiently coexpress trkC at early developmental stages.

\section{Survival}

Treatment of avian and mammalian embryos with antisera against NGF and NT3 demonstrates the requirement for these NTs for nociceptor and proprioceptor survival, respectively. Analysis of mice mutant for NTs and their high-affinity receptors provides details of their developmental role (for reviews, see Snider 1994; Snider and Silos-Santiago 1996).

The mutation of trk receptors leads to the loss of distinct neuron populations by cell death. Mutational inactivation of trkA leads to the loss of nociceptors by increased apoptosis around E13.5 in mouse embryos. Mutational inactivation of trkC results in the loss of proprioceptors by apoptosis around E11. The time course of cell loss in trkB mutant mice is less well documented. Combinatorial trk receptor mutations indicate that a subset of neurons requires trkA and trkB signalling for survival, since cell loss in doublemutants is not additive compared with single mutants (Minichiello et al. 1995). These neurons may be visceral afferents coexpressing trkA and trkB (McMahon et al. 1994). In double-mutants of trkB and trkC, the lack of a parvalbumin-positive neuron population with projections to the intermediate spinal cord layers has been documented, in addition to the absence of proprioceptive afferents (Silos-Santiago et al. 1997).

Neuron loss in NGF mutants occurs embryonically with a time course similar to that in trkA mutants. Moreover, for BDNF mutants, embryonic cell loss similar to that in mutants of its high-affinity receptor trkB has been reported. For NT4, which also signals via trkB, altered neuron numbers have been documented postnatally. In NT3 mutant animals, neuron loss occurs embryonically and postnatally. Even at early embryonic stages, cell loss exceeds that observed in trkC mutants. Complete loss of neurons with proprioceptor markers and a reduction in the number of neurons showing nociceptor markers in newborn animals (Airaksinen and Meyer 1996) demonstrates the obligatory requirement for NT3 in proprioceptor development and an effect on the size of other sensory neuron populations.
Early trkC-expressing cells are completely lost in NT3 mutant animals and neurons positive for trkA and trkB are lost to the same extent as the reduction in total neuron population during embryonic development. Postnatally, NT3 is required for the survival of a cutaneous mechanoreceptor population.

\section{Neurite outgrowth and spinal cord connectivity}

Both the survival-promoting and the neurite-promoting activity of NGF were apparent from the outset. With the intercrossing of NT mutants with mutants for the proapoptotic Bax gene, the analysis of neurite outgrowth defects independent of neuronal cell death has become possible. This kind of analysis has demonstrated that NGF and NT3 are required in the respective afferent subpopulations for peripheral target innervation. Loss of PGP9.5-positive fibres in the cutaneous saphenous nerve and hindlimb skin of trkA/Bax double-mutants and of trkA-positive axons in the distal hindlimb of NGF/Bax double-mutants has demonstrated the NGF requirement for neurite outgrowth to cutaneous targets. The absence of parvalbumin-positive fibres in hindlimb nerves and the decreased axon counts in the soleus nerve of newborn NT3/Bax double-mutant animals demonstrate the NT3 requirement for the peripheral projection of proprioceptors.

Whereas the peripheral projections of both NGF- and NT3-sensitive afferents require NT signalling, central projections differ in sensitivity. Projection appears normal and trkA-immunoreactive fibres are found in the superficial dorsal horn of NGF/Bax double-mutants as in the wildtype. In contrast, proprioceptive axons stop in the intermediate zone of the spinal cord and fail to project to the motor neuron pool in the ventral spinal cord in NT3/Bax doublemutant animals. This shows that both types of fibres can enter the spinal cord in the absence of signalling by the respective NT; they differ, however, in the NT sensitivity of access to the final target. Muscle-derived NT3 allows axonal elongation from the intermediate spinal cord to the ventrally located motoneurons. In addition, the administration of NT3 promotes functional connectivity between Ia afferents and motoneurons postnatally. Thus, NT3 acts as target-derived factor to shape proprioceptor network connectivity. NGF affects connectivity in the dorsal horn of the spinal cord. The mechanisms by which NT exerts its effects and the developmental regulation of these mechanisms remain unknown.

\section{Afferent properties}

On the basis of the observation of lasting hyperalgesia following NGF administration, the alteration of the receptive properties of DRG neurons by NTs in vivo has been 
characterized in some detail. Two types of changes are of interest: modifications in the threshold and response amplitude of existing receptive qualities and the acquisition of new response qualities. These may require different transduction mechanisms, in particular different means of transcriptional and posttranslational regulation and probably differ in their consequences for physiological classification.

The first category includes the reduction in mechanical threshold of A $\delta$ HTMR nociceptors in rat and A $\delta$ AM nociceptors in mouse after excess availability of NGF. Reduction of BDNF levels in mice results in an increase in mechanical threshold of SAM, demonstrating that different NTs affect the response threshold in different sensory neuron populations.

The second category of alterations includes changes in the proportion of heat-responsive $\mathrm{C}$ fibre nociceptors with NGF availability in rat and mice. In this case, mechanosensitive $\mathrm{C}-\mathrm{M}$ nociceptors change to mechanoheat-sensitive $\mathrm{C}-\mathrm{MH}$ nociceptors.

The increase in abundance of $\mathrm{D}$ hair afferents in rats injected with anti-NGF antibodies appears to be of a different quality. The parallel decrease in the abundance of A $\delta$ HTMR units provokes the question as to whether NGF availability leads to phenotypic shifts between nociceptors and LTMR. Different from expectation, no corresponding increase in the percentage of HTMRs is found after NGF injection in rats. In mice overexpressing NGF in skin, however, the prevalence of mechanosensitive A $\delta$ AM nociceptors in saphenous nerve increases from $65 \%$ in control to $97 \%$ in transgenic animals in parallel to an almost complete reduction in the proportion of $\mathrm{D}$ hair afferents.

The mechanisms underlying these NT-induced alterations in afferent properties remain to be determined. An understanding of the properties and regulation of sensory transducers will help to explain the changes in sensitivity to mechanical and thermal stimuli. The mutual regulation of nociceptors and D hair afferents may also include the rerouting of sensory fibres in the target tissue and might involve profound differentiation mechanisms.

\section{Regulation of channel expression}

TRP family channels, Deg/ENaC family channels and voltage-dependent sodium channels are involved in transduction and signal propagation in sensory neurons. Regulation by NTs has been demonstrated for these channel classes.

The proportion of TRPV1- and TRPM8-mRNAexpressing neurons is reduced in DRG of newborn NGF/ Bax double-mutant mice by $30 \%$ and $80 \%$, respectively, demonstrating the regulation of TRP channel expression by NGF during embryogenesis. Long-lasting regulation of heat sensitivity in nociceptors by postnatal NGF administration in rats indicates that TRP channel expression is also regulated by NGF after birth, even though the molecular changes have not yet been characterized. In adult rats, TRPV1 and TRPA1, but not TRPM8, expression in DRG is increased during inflammation. The blockage of this increase by anti-NGF antibodies demonstrates that NGF also affects TRP channel expression in adult DRG neurons. Thus, TRPV1 expression appears sensitive to NGF signalling at all developmental stages and in vitro results suggest that the effects may be direct. The role of NGF in the maintenance of physiological expression levels in postnatal animals, other than induction by inflammatory processes, has not been analysed, however. In addition to alterations in mRNA and protein expression, rapid posttranslational regulation occurs in adult animals and may entail the phosphorylation of TRP channel protein and transport to the plasmamembrane.

In BDNF mutants, ASIC2 expression is reduced in parallel to a reduction in mechanosensitivity of slowly adapting low-threshold receptors (SAM). Culture experiments indicate that BDNF directly affects neuronal expression of a putative mechanosensor and suggest the need for further developmental analysis.

Transgenic NGF overexpression in skin increases the expression of voltage-gated sodium channels. The mRNA levels for Nav1.8/SNS sodium channels in DRG neurons are enhanced in DRG of transgenic animals. Protein levels in A fibre nociceptors correlate with trkA expression in wildtype animals. The regulation of sodium channel expression by NTs during development remains to be characterized in more detail.

\section{Lineage specification}

Analysis of NGF/Bax and trkA/Bax double-mutant mice has shown that trkA signalling is required for the differentiation of peptidergic nociceptors. In DRG of newborn trkA/Bax double-mutant mice, SP and CGRP, the population-specifying markers of peptidergic nociceptors, are undetectable, even though cell death is prevented by the Bax mutation. The induction of CGRP expression in cultures of DRG explants from Bax single mutants shows that NGF may induce neuropeptide expression with a normal time schedule. This suggests that NGF supports peptidergic differentiation in vivo directly but does not definitively establish that other signalling systems are not required. The presence of a large number of CGRP-negative neurons in NGF-treated cultures from Bax mutant mice and in dissociated cultures from rat DRG neurons at E12.5 and E14.5 provokes the question of whether neurons are prespecified to a peptidergic or non-peptidergic phenotype. 
In NGF/Bax double-mutants, only a few strong retpositive neurons are present at $\mathrm{P} 0$; these are trkA-negative. This observation shows that NGF signalling is also involved in the differentiation of those ret-expressing neurons that develop from trkA-expressing cells and give rise to non-peptidergic nociceptors.

The trk receptors themselves are important lineage markers expressed early during DRG development. Because of their coexpression with trkC during the initiation of trkA or trkB expression, which amounts to $100 \%$ of the respective cells in chick DRG, the precise onset of differentiation is not well specified by the trk pattern. trkC expression is restricted to a small subpopulation of DRG neurons only with ongoing development. The mechanism underlying this process is not as yet known. Moreover, the signals involved in the acquisition of trkA expression in the vast majority of DRG neurons during midembryonic development remain to be determined. In newborn NGF/ Bax double-mutant mice, trkA expression is rescued (Patel et al. 2000) and, in rats injected with NGF or anti-NGF antiserum postnatally for 2 weeks, the proportion of trkApositive neurons is not altered (Molliver and Snider 1997). The data indicate that NGF is not required for trkA expression. Furthermore, the initiation of trkA expression appears normal in NT3 mutant mice.

An effect on the trk expression pattern in DRG has been reported for NT4. Mutation of NT4 reduces the proportion of trkB-expressing and increases that of trkC-expressing DRG neurons in newborn mice (Liebl et al. 2000). In adult NT4-overexpressing animals, the opposite alterations are observed (Krimm et al. 2006). The mechanism of this effect still needs to be resolved.

In mice in which trkA is replaced by the coding sequence for trkC, 600-700 neurons in L4 and L5 ganglia express the proprioceptor marker parvalbumin as compared with 200-500 in the wildtype (Moqrich et al. 2004). The authors conclude that $8 \%$ of the presumptive trkA neurons switch to a proprioceptive phenotype. This study may present the most direct evidence for lineage specification by NT signalling. The switch, however, affects only a small percentage of the neurons with altered trk expression. Because of the restricted size of the affected population and its unknown fate in wildtype animals, the results are difficult to judge.

\section{Functional analysis of NT signalling in the sympathetic system}

The discovery of a dramatic hypertrophy of sympathetic ganglia in chick (Levi-Montalcini and Hamburger 1951) and several mammalian species (Levi-Montalcini and Booker 1960a, b) induced by NGF can be considered as the key step for the molecular analysis of neuronal development. The correlation of NGF levels in rat organs with sympathetic innervation density (Korsching and Thoenen 1983) and the developmental time course of NGF availability (Korsching and Thoenen 1988) strongly supported the concept that NGF production in target organs determines the density of sympathetic innervation.

The daily injection of purified NGF in postnatal mice results in a two- to three-fold increase in the size and cell number of thoracic sympathetic ganglia (Levi-Montalcini and Booker 1960a) and SCG (Black et al. 1972). Conversely, the application of anti-NGF antiserum leads to a massive loss of neurons from the SCG in postnatal mice and other mammalian species (Levi-Montalcini and Booker 1960b; Angeletti et al. 1972): cell counts in experimental animals analysed between P20 and P120 amount to $\sim 1 \%$ of the control. Similarly, anti-NGF injection in newborn rats, rabbits and cats leads to more than an $80 \%$ reduction in sympathetic ganglion cell counts.

The effects of anti-NGF antiserum differ between paravertebral and prevertebral sympathetic ganglia. Treatment of newborn rats for 5 days after birth results in the massive atrophy of SCG and stellate ganglia (STG), whereas mesenteric ganglia appear normal in size and structure (Vogt 1964; Zaimis et al. 1965). Moreover, retrograde labelling of sympathetic neurons in rats injected neonatally with antiNGF antiserum show a smaller loss of neurons in mesenteric compared with other sympathetic ganglia (Hill et al. 1985).

The SCG and other sympathetic ganglia are affected not only by postnatal, but also by prenatal application of the antiserum (Klingman and Klingman 1967). Injection of antiserum into pregnant mice at days 15,16 and 17 leads to $\sim 80 \%$ cell loss in STG and SCG of progeny analysed postnatally. Conversely, transuterine injection of NGF in embryonic mice increases the number of catecholaminergic neurons (Kessler and Black 1980a).

NGF dependence is less acute in adult mice. Repeated injection of NGF leads to an increase in the size of sympathetic ganglia but not in neuron number in STG and SCG (Levi-Montalcini and Booker 1960a). Daily injections of anti-NGF antiserum for five consecutive days results in a marked size reduction of the sympathetic chain; this is only partly attributable to cell death (Angeletti et al. 1971a). Instead, reversible changes in neuron size appear to be involved. The long-term exposure to anti-NGF antibodies by injection into mice for several weeks, however, leads to a significant reduction of the cell number in SCG (Levi-Montalcini and Booker 1960b; Ruit et al. 1990). The cell loss develops progressively and depends on antibody titer. In animals treated with high titer antisera, $70 \%$ cell loss has been reported after daily application for 1-3 months.

Analysis in mutant mice has confirmed the central role of NGF for sympathetic neuron survival and specified the 
timing of the requirement for NGF during embryonic development. The tight correlation of deficiencies in the sympathetic neuron number of NGF and trkA mutant mice contrasts with the differences in neuron losses of NT3 and trkC mutant mice, as discussed below. The findings demonstrate that NGF acts via trkA, whereas NT3 is not restricted to signalling via trkC in sympathetic neuron differentiation. No significant change in SCG size and no decrease in neuronal counts have been observed in BDNF mutant mice (Ernfors et al. 1994a; Jones et al. 1994). Rather, neuron number is slightly but not significantly increased (114\% of wildtype; Ernfors et al. 1994a). Similarly, no effect on the SCG has been observed in trkB mutant mice (Fagan et al. 1996). This, in agreement with trk expression patterns, shows that signalling through trkA and trkC, but not trkB, is important for the development of the majority of sympathetic neurons.

Analysis of mutant mice demonstrates the requirement of NGF signaling for sympathetic neuron survival during the third embryonic week

Mutation of the gene coding for NGF results in dramatic cell losses in sympathetic ganglia. The SCG have disappeared by P14 (Crowley et al. 1994), with pyknotic nuclei at postnatal stages documenting cell death. Even in newborn animals, the majority of cells is lost in SCG and STG (Francis et al. 1999; Glebova and Ginty 2004). Whereas no significant cell loss is observed at E15.5 and E16.5, reduced numbers of ganglion cells are detected from E17.5 onwards. Similar to the situation in NGF mutant mice, the loss of functional highaffinity NGF receptors by mutation of the trkA kinase domain leads to a severe reduction in the size of SCG and other sympathetic ganglia (Smeyne et al. 1994). Whereas no obvious difference has been observed between trkA mutant and wildtype SCG at E11.5 and E13.5, a reduction in cell number has been reported at E15.5 (15\%) and E17.5 (35\%; Fagan et al. 1996). During these developmental stages, increased numbers of pyknotic nuclei indicate excessive cell death. Thus, mutation of NGF or its high-affinity receptor trkA lead to comparable amounts of ganglion cell loss by cell death starting during the third week of embryonic development.

NT3 availability affects sympathetic ganglion cell number at developmental stages when neurons are also NGF-dependent

A reduction of sympathetic ganglion cell number also occurs in NT3 mutant mice and is reported to be $35 \%-50 \%$ for newborn SCG (Farinas et al. 1994; Ernfors et al. 1994b; Tessarollo et al. 1997; Francis et al. 1999) and 27\%-46\% for STG (Francis et al. 1999; Story et al. 2000). In contrast, mutation of the high-affinity receptor for NT3, trkC, does not lead to alterations in SCG cell numbers at E13.5-P9 (Fagan et al. 1996; Tessarollo et al. 1997), indicating that NT3 can act via trkA during sympathetic development.

An early study reporting neuron loss in SCG in NT3 mutants between E11 and E17 attributable to increased apoptosis (ElShamy et al. 1996) has not been confirmed by other laboratories. In three laboratories, no alteration in ganglion cell number has been observed at E15.5 and E16 (Wyatt et al. 1997; Francis et al. 1999; Kuruvilla et al. 2004) and the number of pyknotic cells is unaltered (Wyatt et al. 1997; Francis et al. 1999). Rather, significant cell loss is detected from E17.5 onwards and, at E17.5-P1, significantly more pyknotic cells are found in mutant SCG (Wyatt et al. 1997; Francis et al. 1999).

In compartmentalized cultures of sympathetic neurons from newborn rat, NT3 supports survival only when applied to cell bodies, not when given to distal axons (Kuruvilla et al. 2004). In contrast, NGF supports survival when applied to cell bodies or to axons. The results indicate that NT3 in vivo may not be required as a survival factor per se but promotes the access of growing nerve fibres to target-derived NGF for survival (see below). This is in accordance with the relatively late onset of cell death that coincides with the stage of NGF dependence in NT3 mutant mice (Francis et al. 1999). Further support comes from the finding that sympathetic neuron loss in SCG of E17.5 NGF-deficient mice is not exacerbated by mutation of NT3 (Francis et al. 1999).

NGF availability promotes peripheral innervation

Postnatal injection of NGF in mice results in an increased density of fibres in target organs and innervation of normally non-innervated tissues (Levi-Montalcini and Booker 1960a; Olson 1967). Correspondingly, neonatal rats injected with NGF show a two-fold increase of noradrenalin in the heart (Kornblum and Johnson 1982). Six daily NGF injections in adult mice result in increased catecholamine fluorescence intensity and density of the nerve terminal plexus in various sympathetic target tissues (Bjerre et al. 1975). Two months after this treatment, these effects have almost totally disappeared. The authors conclude that NGF reversibly stimulates collateral sprouting in sympathetic target tissues.

Conversely, prenatal or postnatal injection of anti-NGF antiserum in mice leads to reduced catecholamine levels in sympathetic target tissues (Klingman and Klingman 1967). The reduction of catecholamine levels in target tissues after antiserum injection in postnatal rats correlates with the reduction of the ability of these tissues to take up radiolabelled noradrenalin (Zaimis et al. 1965). Differences in the decrease in noradrenalin uptake between various 
target tissues (Zaimis et al. 1965; Iversen et al. 1965) are in accordance with the different losses of sympathetic neurons across prevertebral and paravertebral sympathetic ganglia upon treatment with anti-NGF antiserum. Application of antiserum on five consecutive days in adult mice leads to a reduction in the noradrenalin content of various target tissues; this recovers partially within weeks after cessation of the antibody treatment (Angeletti et al. 1971a).

Thus, NGF application increases sympathetic fibre density in target organs and the antiserum reduces biochemical indicators of sympathetic target innervation. Upon electron-microscopical examination of sympathetic ganglia in NGF-treated newborn or adult mice, the most prominent feature is a massive increase in neurofilaments and neurotubuli (Angeletti et al. 1971b). This observation together with the analysis of the regulation of $\mathrm{T} \alpha 1$ tubulin expression shows that NGF may affect the availability of neuron-specific cytoskeletal components.

Daily NGF injection from P2 to P11 in rats prevents the decrease in T $\alpha 1$ tubulin mRNA levels in SCG observed by Northern blotting in untreated animals during the corresponding developmental period (Mathew and Miller 1990). Culture studies with dissociated neurons from newborn rat SCG show that the increase in T $\alpha 1$ tubulin mRNA levels depends on the NGF concentration with a time course different from that of $\mathrm{TH}$ induction (Ma et al. 1992; see also below). In PC12 cells, the NGF-induced increase in $\alpha$ tubulin mRNA levels precedes neurite extension (for discussion, see Mathew and Miller 1990) and is attributable to an elevation of transcription rate, different from the increase in steady state TH mRNA levels (Miller et al. 1991). The authors conclude that the induction of $\mathrm{T} \alpha 1$ tubulin reflects a generalized growth response and correlates with collateral sprouting in the terminal arbour.

Transgenic overexpression confirms the role of NTs in sympathetic neuron survival and target innervation

Experiments involving the administration of exogenous NGF have been extended by the overexpression of NGF, via a K14 keratin promoter, in the epidermis of transgenic animals: SCG neuron number is increased 2.7-fold as analysed postnatally (Davis et al. 1996) and sympathetic innervation in the skin is increased, as shown by IHC for TH (Albers et al. 1994). Sympathetic innervation of target organs has been analysed in detail in footpads (Guidry et al. 1998). The temporal sequence of footpad innervation is not affected in the NGF-overexpressing animals. Axon partitioning in the target tissues, however, is disrupted. Sweat glands and blood vessels, the two sympathetic targets in footpads of wildtype animals, lack substantial innervation in transgenic animals. Instead, a dense plexus of catecholaminergic sympathetic fibres appears in the dermis.
Similarly, in whisker-pad skin of transgenic mice, THimmunoreactive fibres are found throughout the dermis and adjacent to the epidermis (Davis et al. 1996). In contrast, in control mice, TH-positive fibres are found in the dermis primarily associated with blood vessels.

In transgenic mice expressing BDNF under the control of the $\alpha$-myosin heavy chain promoter, enhanced BDNF protein levels are detected in skin, where mRNA is found in the subcutaneous muscle layer, not in the arrector pili muscle or the vascular tunica muscularis (Botchkarev et al. 1998). A substantial TH-positive hyperinnervation of arrector pili muscle and surrounding dermis is evident in these animals. Whether this affects the minor trkB-positive population of sympathetic neurons or is mediated by the low-affinity NT receptor p75 remains to be resolved.

Expression of a NT3 transgene under the control of a human K14 keratin promoter in basal skin keratinocytes in mice results in a $32 \%$ increase in the number of SCG neurons as compared with control animals (Albers et al. 1996). No data on sympathetic target innervation are presented in this study, however.

Analysis of mutant mice shows effects of NGF and NT3 at different stages of sympathetic neurite outgrowth

In trkA mutant mice, the initial axon outgrowth from the SCG at E13.5, as analysed by IHC for TH, does not differ from that in wildtype animals (Fagan et al. 1996). At later stages, however, sympathetic target innervation is compromised. The submaxillary gland, a distant target that first receives TH-positive fibres in wildtype animals at E15.5, shows no significant $\mathrm{TH}$ immunoreactivity in trkA mutants throughout embryonic development. In NGF-deficient mice, a variable phenotype of salivary gland innervation has been reported at E17.5, with TH-positive fibres being detected in three out of five mutant animals and with two animals lacking salivary gland innervation entirely (Francis et al. 1999). The requirement for NT signalling in neurite outgrowth has been analysed in more detail by wholemount IHC for $\mathrm{TH}$ in mice double-mutant for Bax and NGF (Glebova and Ginty 2004). In these animals, NGF is not required for sympathetic neuron survival such that neurite outgrowth is not compromised by cell death. At E16.5, proximal projections from the SCG, STG and sympathetic chain ganglia appear grossly normal. In neonatal NGF/Bax double-mutant mice, sympathetic target innervation is absent in certain organs such as the salivary glands, is strongly reduced in others such as the heart, is slightly reduced in a few organs such as the stomach and kidneys and is not reduced in some structures such as the trachea (Glebova and Ginty 2004). Interestingly, NGF is not required for axon extension along arteries; the NGF requirement may become apparent when sympathetic fibres 
leave arteries to innervate organ parenchyma as observed in the spleen.

In NT3 mutant mice, unlike NGF mutant animals, proximal axon extension along the vasculature around the SCG, as analysed by whole-mount IHC for TH, is impaired even at E15.5 when neuron numbers in the ganglion are not affected (Kuruvilla et al. 2004). In addition, STG projections to the heart at this stage are shorter in NT3 mutants as compared with wildtype littermates. At later stages, sympathetic end-organ innervation is strongly compromised in the absence of NT3. At P0.5, the hearts of NT3/Bax double-mutant animals show markedly reduced levels of sympathetic innervation as compared with Bax mutant mice (Kuruvilla et al. 2004). Two other studies, however, report normal innervation of NT3 mutant hearts by TH-positive sympathetic fibres at birth (Story et al. 2000) and at P15 (ElShamy et al. 1996). Cardiac noradrenalin concentrations are found to be equivalent among wildtype and NT3 mutant mice at birth but differences become apparent with age (Story et al. 2000). NT3 elimination affects the innervation of the various targets differently. Staining of sympathetic nerve fibres with IHC for TH and glyoxylic acid fluorescence at P15 shows a similar to normal nerve fibre ground plexus in the NT3 mutant iris and submandibular gland but the complete absence of sympathetic innervation in the pineal gland and external ear (ElShamy et al. 1996). In the pineal gland and external ear, the absence of TH-positive sympathetic nerve fibres is observed at all stages examined, in accordance with a requirement for NT3 during early neurite outgrowth.

In vitro studies suggest an NGF effect on neuron-target connectivity

In cultures of SCG neurons and ventricular myocytes from neonatal rat, NGF perfusion leads to an acute increase in the beating rate of myocytes (Lockhart et al. 1997). In addition, long-term effects are observed in cocultures grown for 3 days with two NGF concentrations that both support neuronal survival. The myocyte response to neuronal stimulation is greater in $50 \mathrm{ng} / \mathrm{ml} \mathrm{NGF}$ than in $5 \mathrm{ng} / \mathrm{ml} \mathrm{NGF}$ and the connection probability is increased. No difference in basic electrophysiological features such as the resting membrane potential is observed but the proportion of myocytes with dense neuritic contacts varies with NGF (Lockhart et al. 2000). The number of SV2containing neurite endings is increased at higher NGF concentrations and by interaction with mature myocytes. A molecular analysis of the promotion of contact formation between sympathetic neurons and their targets will be of great interest. In cultured sympathetic neurons of young chick embryos, NGF directly affects the splicing of neurexin I (Patzke and Ernsberger 2000). This presynaptic protein binds to neuroligins and associates with calcium channels and, thus, may play a crucial role in synapse organization and function.

NGF promotes dendritic growth and preganglionic innervation

Daily subcutaneous injection of NGF in newborn rats for 1 or 2 weeks results in an increase in the number of primary dendrites, the total dendritic length and the extent of dendrite branching in SCG neurons as revealed by intracellular staining of individual SCG cells after filling with HRP or Lucifer yellow (Snider 1988; Ruit and Snider 1991). Conversely, treatment with anti-NGF antiserum for the first three postnatal weeks reduces the number of primary dendrites, the total dendritic length and the extent of dendrite branching (Ruit and Snider 1991). In adult mice, alteration of NGF levels affects total dendritic length and the number of dendrite branch points, but not the number of primary dendrites (Ruit et al. 1990). In cultures of SCG neurons from perinatal rats, the NGF concentration affects the number of dendrites per neuron and the percentage of neurons with dendrites (Lein et al. 1995). In this latter study, cells were supplemented with saturating concentrations of bone morphogenetic protein 4 in addition to variable concentrations of NGF. Since cell number is affected in a similar way as dendritic growth, NGF effects on neuron survival and process outgrowth cannot be readily separated.

Microelectrode intracellular recordings on sympathetic neurons from guinea-pigs treated with anti-NGF antiserum demonstrate an NGF requirement for sympathetic neuron connectivity ( $\mathrm{Njå}$ and Purves 1978). SCG isolated with attached preganglionic and postganglionic nerves at 58 days after the last of four daily injections of anti-NGF antiserum show abnormal postsynaptic potentials with low amplitude after stimulation of preganglionic nerve trunks. The mean number of synapses per unit area is reduced by $48 \%$ in treated ganglia and the area of presynaptic profiles is smaller as analysed by electron microscopy. Ganglia in the treated animals are of normal size and neuron number, showing that the effect on synaptic transmission is independent of neuronal survival and that the antiserum doses were too low or the application too short to induce cell death. No difference in the effect has been described upon the grouping of experimental animals by age between P4 and sexual maturity. The application of exogenous NGF, however, has no effect on the function or number of synapses (Njå and Purves 1978). This indicates that the endogenous supply is saturating for connectivity in surviving neurons but might also be attributable to the experimental set-up. 
NGF regulates ionic currents in sympathetic neurons

Injection of NGF and anti-NGF antibodies into adult leopard frogs affects the calcium conductances recorded from sympathetic ganglion B cells (Lei et al. 1997). Recordings from dissociated cells acutely isolated on days 9 or 10 from animals that had received subcutaneous injections every other day on days 1-7 show a 56\% increase of the whole-cell barium current upon NGF injection and a $20 \%$ decrease of the current upon antibody injection. In cell culture, the current decreases over a 15day culture period; this decrease can be prevented by NGF. Both N-type and L-type currents are affected. Under the same in vitro conditions, TTX-sensitive and TTXR sodium currents are also increased by NGF (Lei et al. 2001; Ford et al. 2008), although delayed rectifier and M-type potassium currents remain unaffected.

However, NGF effects on potassium conductances have been shown in avian and mammalian sympathetic neurons in vitro. In lumbar sympathetic neurons taken from E13 chick and cultured for 5 days, NGF increases calciumdependent potassium currents $\left(\mathrm{IK}_{\mathrm{Ca}}\right)$ as analysed by wholecell recordings (Raucher and Dryer 1995). The bimodal distribution of the current densities in NGF-treated cultures, in which half of the neurons show large current amplitude, indicates the presence of different neuronal subpopulations. Whether NGF contributes to the increased survival of a neuronal subpopulation with a high $\mathrm{IK}_{\mathrm{Ca}}$ current density or induces $\mathrm{IK}_{\mathrm{Ca}}$ currents in an existing subpopulation of neurons is unclear from this study. In 2- to 4-day cultures of neonatal rat SCG neurons supplemented with $5 \mathrm{ng} / \mathrm{ml}$ NGF for survival, acute treatment with $50 \mathrm{ng} / \mathrm{ml} \mathrm{NGF}$ affects neuronal excitability and diverse potassium currents (Luther and Birren 2006). NGF increases the current threshold for action potential initiation, hyperpolarizes the resting membrane potential, reduces the number of spikes per stimulus but increases the firing frequency resulting in a phasic discharge. Again the data show a bimodal distribution indicating multiple neuron groups that differ in their firing properties and NGF response. The isolation of the calcium-independent potassium current by TTX and cobalt chloride shows that the amplitude of all three kinetically separated potassium currents activated upon depolarizing voltage commands are decreased by NGF. Moreover, calcium-dependent potassium currents measured from tail currents are significantly smaller after an NGF challenge. Different from sympathetic neurons from chick embryos, NGF decreases $\mathrm{IK}_{\mathrm{Ca}}$ in neonatal rat SCG cells.

In SCG neurons of 4- to 6-week-old rats, acute NGF application results in a rapid inhibition of $\mathrm{M} / \mathrm{KCNQ}$ currents (Jia et al. 2008). Cells have been recorded in a whole-cell patch and perforated whole-cell patch configuration within $48 \mathrm{~h}$ in culture in the absence of NGF followed by NGF supplementation at $20 \mathrm{ng} / \mathrm{ml}$ for $2 \mathrm{~min}$. The excitability of tonic neurons, but not of phasic neurons, is increased by NGF and the spike number but not the resting potential is increased in tonic neurons. $\mathrm{M} / \mathrm{KCNQ}$ currents, pharmacologically separated by sensitivity to linopiridine, are inhibited by the NGF challenge. Current inhibition follows immediately after NGF addition with a time constant of single exponential decay at $\sim 100 \mathrm{~s}$. The results indicate a rapid posttranslational regulation resulting in a reduced single channel open probability. Inhibition starts at $0.05 \mathrm{ng} / \mathrm{ml} \mathrm{NGF}$ and reaches a maximum at $20 \mathrm{ng} /$ $\mathrm{ml}$, strongly suggesting signalling via the high-affinity NGF receptor trkA.

These studies show that NGF can regulate calcium currents in frog sympathetic neurons in vivo. The regulation of calcium and sodium conductances in vitro indicates that NGF directly acts on the neurons. In addition, NGF affects diverse potassium conductances in avian and mammalian sympathetic neurons in vitro. The way in which the potassium currents, their differential expression in sympathetic neuron subpopulations and their control of neuronal excitability are regulated by NGF throughout development in vivo is currently unclear. Whether NGF regulates sodium and calcium conductances in amniote sympathetic neurons is also of interest.

\section{Alteration of NGF availability affects noradrenergic properties in sympathetic neurons}

NGF injection into newborn rats augments noradrenergic transmitter properties. Daily injections for 5 days to 3 weeks result in a specific increase in $\mathrm{TH}$ and $\mathrm{DBH}$ activity (Thoenen et al. 1971; Hendry 1975). 3,4-Dioxyphenylalanine decarboxylase (DDC) and monoamine oxidase increase to the same extent as total protein. Even a single injection of NGF at doses below those required for an increase in ganglionic protein content elevates $\mathrm{TH}$ activity in rat SCG (Stöckel et al. 1974; Kornblum and Johnson 1982). Conversely, a single anti-NGF antiserum injection into newborn rat decreases the activity of $\mathrm{TH}, \mathrm{DBH}$ and monoamine oxidase (Angeletti et al. 1972). Moreover, in newborn mice, single doses of NGF or anti-NGF injection increase or decrease, respectively, $\mathrm{TH}$ activity in SCG (Hendry and Iversen 1971; Hendry 1973).

The TH response to NGF in SCG changes with age. The increase in TH activity after a single NGF injection in adult rat SCG is smaller than that in newborn animals (Otten et al. 1977). Upon single injection of anti-NGF at P2, a marked irreversible drop of TH, DBH and DDC activities occurs while a single injection at P30 results in smaller enzyme reductions which are completely reversible (Goedert et al. 1978; compare Hendry and Iversen 1971). Immunization of adult rats results in decreased total enzyme 
activities for TH, DBH, and DDC in SCG; these partially recover 7 months after the last booster when antibody titers have decreased (Otten et al. 1979).

Transuterine injection of NGF in mouse embryos increases TH activity in SCG at all gestational stages analysed (Kessler and Black 1980a). This results from an increase in the number of catecholaminergic neurons and an increased activity per neuron as analysed at E17 after injection at E15. Anti-NGF injection at E12 leads to a TH reduction with incomplete recovery, whereas treatment at E15 results in a marked TH reduction that does not recover within a 5-week analysis period.

Cultures of sympathetic neurons have been instrumental for analysing the mechanism of TH induction by NGF. Explant cultures of SCG from adult rats show an increase of specific TH activity by NGF during a 2-day culture period; this is attributable to increased enzyme protein synthesis as shown by $\left[{ }^{3} \mathrm{H}\right]$ leucine incorporation (Max et al. 1978). Since the induction is not inhibited by the RNA synthesis blockers $\alpha$-amanitin or actinomycin D in cultures of sympathetic neurons at various developmental stages (Rohrer et al. 1978; Hefti et al. 1982), a posttranscriptional mechanism must be responsible. Surprisingly, TH mRNA levels as analysed by Northern blot increase specifically and to a similar magnitude as specific $\mathrm{TH}$ activity after NGF treatment in 15- to 20-day cultures (Raynaud et al. 1988). TH mRNA levels start to increase at $12 \mathrm{~h}$ after NGF addition and are NGF-concentration-dependent as analysed after 5 days of culture (Ma et al. 1992). In vivo after NGF injection into newborn rats from P2-P11, TH mRNA is increased more than 10 -fold as analysed by Northern blot (Miller et al. 1991).

These studies show that NGF affects TH activity in sympathetic ganglia in vivo and in vitro. This is achieved by increased enzyme protein synthesis and enhanced steady state mRNA levels but not increased transcription.

NT3 and NGF oppositely regulate cholinergic and noradrenergic properties in vitro

In explants of sympathetic ganglia taken from E12 chick and grown for 4 days in culture, NT3 promotes the cholinergic markers ChAT and VIP but not the noradrenergic markers NET and TH as analysed by RT-PCR (Brodski et al. 2002). NGF promotes the noradrenergic but not the cholinergic markers. Results from the addition of NT3 and NGF alternately suggests that the effects are not attributable to selective survival but to alterations in mRNA levels.

Thus, NTs might regulate the differentiation of neurotransmitter phenotype in vitro. In NT3 mutant mice, however, the postnatal shift from noradrenergic to cholinergic properties of sympathetic innervation to the sweat glands appears to be unaffected, as revealed by IHC for acetylcholinesterase and VIP (ElShamy et al. 1996). Unfortunately, no data on the expression of ChAT in NT3 mutant mice at various developmental stages are available.

\section{Summary}

\section{trk expression}

The vast majority or even all mature sympathetic neurons express the high-affinity NGF receptor trkA. A number of studies from various mammalian species concur in showing that trkC is expressed in only a small neuronal subpopulation $(10 \%-20 \%)$ in adult animals. trkB is found in a negligible fraction of mature sympathetic neurons.

During mouse embryonic development, trkC is detectable at E11.5 in SCG and is expressed throughout the ganglion at E13.5. Subsequently, trkC becomes restricted to a small subpopulation detectable at birth. trkA expression in mouse SCG is first found at E13.5 and increases to become strong and widespread at birth. A similar sequence of trkA and trkC expression is observed in sympathetic ganglia during rat embryonic development. Likewise, in chick embryos, trkC expression commences early and is downregulated in secondary sympathetic ganglia where trkA becomes prominently expressed.

In chick embryos, coexpression of trkA and trkC immunoreactivity is reported at early stages of sympathetic neuron differentiation. Moreover, trkB and trkC immunoreactivities colocalize during early development but this is at variance with ISH data for trkB. With ongoing development, trkA and trkC expression segregate to different neuron populations. Noradrenergic and cholinergic properties segregate with trkA and trkC expression, respectively, in chick sympathetic ganglia.

\section{Survival}

Even though the onset of trkA and trkC expression differs by 2 days in mouse embryonic development, the timing of cell loss in NGF and NT3 mutant mice is similar and becomes significant at E17.5. Moreover, no cell loss is observed in trkC mutant mice suggesting NT3 action via trkA. In trkA mutants, a small but significant cell loss is reported even at E15.5; this may have been missed in the NT mutants because of differences in the sampling method and size.

The stringent requirement of NGF for survival persists postnatally but is not apparent in mature animals. Although embryonic and postnatal NGF depletion results in an immediate loss of large numbers of sympathetic neurons, short-term NGF depletion in adult rats leads to a reduction in cell size, ganglion volume and protein content, whereas 
cell number appears unaffected. Only long-term NGF deprivation for several weeks to months results in largescale cell loss.

\section{Neurite outgrowth}

The tight temporal correlation of cell death in NGF and NT3 mutant animals suggests that the action of one factor may not directly promote survival but provide access to the other factor by stimulating neurite outgrowth. Indeed, NT3 is required for early neurite outgrowth even in the vicinity of the SCG. NGF also promotes neurite extension but, at later stages, close to the targets. Terminal sprouting appears to be under NGF control.

Different from the effects of NT gene mutations on sympathetic neuron numbers, the published effects on neurite outgrowth differ clearly between animals and laboratories. Whether this is attributable to specimen selection or strain differences is unclear. It points, however, to the crucial involvement of other factors in the regulation of neurite access from ganglia to target.

Interestingly, the overexpression of NGF in epidermis disrupts axon partitioning in the target by redirecting sympathetic nerve fibres normally destined to innervate sweat glands and blood vessels to alternate targets in the dermis. This result shows that responsive neurites do not simply project to the growth factor source in the epidermis.

\section{Formation of synaptic connections}

NGF has the potential to affect the connectivity of sympathetic neurons with preganglionic innervation and with peripheral target tissues. NGF application in newborn rats enhances dendritic growth and complexity and treatment with anti-NGF antiserum in guinea-pigs at different postnatal to adult stages reduces synapse density, presynaptic area and the amplitude of postsynaptic potentials. The studies show that NGF is required for the normal development of synaptic connectivity between preganglionic and postganglionic sympathetic neurons in vivo. A molecular analysis of the underlying changes to reveal whether the effect is presynaptic and/or postsynaptic would greatly promote our understanding of NT actions.

In vitro studies indicate that NGF is also involved in the development of target innervation. In coculture with myocytes, NGF alters the effect of sympathetic neuron stimulation on myocyte beat rate acutely and over extended periods. Molecular evidence for the number of synaptic sites suggests that synapse formation may be involved in the process.

NGF, in collaboration with other in part uncharacterized factors, shapes connectivity between preganglionic and postganglionic sympathetic neurons and between postganglionic sympathetic neurons and target cells.

\section{Regulation of $\mathrm{TH}$}

NGF injection leads to a specific increase in TH activity in sympathetic ganglia of rats and mice at all stages from embryogenesis to adulthood. In vitro, the NGF-induced increase in specific enzyme activity in sympathetic neurons is attributable to increased protein synthesis. In spite of a similar increase in TH mRNA levels after NGF treatment in vitro, the increase in enzyme activity is not sensitive to RNA synthesis blockers suggesting posttranscriptional regulation. In PC12 cells, the NGF-induced increase in TH mRNA levels has been shown to occur both posttranscriptionally and transcriptionally (Leonard et al. 1987; Gizang-Ginsberg and Ziff 1990; Miller et al. 1991). Together with the rapid activation of $\mathrm{TH}$ activity within minutes of NGF administration by enzyme phosphorylation in PC12 cells (Greene et al. 1984; McTigue et al. 1985), NGF may engage a range of pathways to stimulate the noradrenergic transmitter phenotype on different time scales from minutes to days.

\section{Transmitter phenotype}

The induction of TH and NET mRNA by NGF and of ChAT and VIP mRNA by NT3 in explants of sympathetic ganglia from E12 chick strongly suggests a role of NT signalling in the specification of sympathetic transmitter phenotypes (Brodski et al. 2000). Importantly, the effect of one factor can be reversed by the other factor, presumably without major cell loss. This provokes the question as to whether NTs specify early sympathetic neurons coexpressing both noradrenergic and cholinergic properties to develop into cells with only one or the other phenotype. The postnatal shift in vivo from noradrenergic to cholinergic sympathetic innervation of sweat glands appears unaffected by NT3 mutation (ElShamy et al. 1996) but depends on gp130 signalling (Stanke et al. 2006). The prenatal segregation of lineages in mouse after E13 is in part ret-dependent (Burau et al. 2004). Contributions by trk signalling to sympathetic transmitter specification in vivo remain to be further analysed.

\section{Regulation of ion channels}

Potassium conductances, in particular calcium-dependent potassium currents and $M$ currents, contribute to the diversity of the electrophysiological properties of sympathetic neurons and appear differently expressed in neuronal subpopulations (Jänig and McLachlan 1992). In vitro studies in birds and mammals show that NGF affects these 
potassium conductances. A developmental analysis in vivo of acute and long-term effects of NT signalling on potassium conductances in avian and mammalian sympathetic neurons is still missing.

Moreover, the regulation of calcium and sodium conductances by NGF is of interest. In frog sympathetic neurons, calcium conductances are sensitive to NGF levels in vivo and the regulation of calcium and sodium currents has been demonstrated in vitro. In rat PC12 cells, sodium currents and various sodium channel transcripts are induced by NGF (Mandel et al. 1988; D’Arcangelo et al. 1993).

\section{Concluding remarks}

trk expression and survival action of NTs

The developmental pattern of trk expression shows remarkable similarities in the two neuronal lineages under consideration. During DRG and sympathetic neuron development, trkC is expressed before trkA and trkB. $\operatorname{trkC}$ is initially expressed throughout the ganglia and then is downregulated to a small subpopulation of neurons. trkB and trkA become expressed later when the ganglionic cell population is expanding.

In the chick embryo, the neurons initiating trk $A$ and trkB expression temporarily coexpress trkC. In the mouse embryo, extensive overlap of trkB and trkC expression has been reported during early phases of trkB expression in DRG neurons. The segregation of trk expression to different neuronal subpopulations becomes prominent only later.

The progressive embryonic restriction of trkC and trkB expression in combination with the acquisition of trkA expression in the majority of neurons leads to the formation of subpopulations of sensory and autonomic neurons with specific trk expression patterns and, as shown for DRG neurons, distinct target tissues. In newborn mammals, the large majority of DRG sensory neurons and sympathetic autonomic neurons express trkA. Small proportions of neurons express trkB and trkC. The ret-dependent postnatal downregulation of trkA expression has been documented for a population of DRG neurons.

Depletion by immunization or antibody injection demonstrates the survival requirement for NGF of the vast majority of sympathetic and DRG neurons during embryonic development, as has been confirmed in NGF and trkA mutant mice. Whereas NGF dependence lasts into the postnatal period for sympathetic neurons, DRG neurons lose their NGF requirement for survival within the first few postnatal days. In NGF and trkA mutant mice, cell death in DRG precedes that in sympathetic ganglia. Cell loss commences at the same developmental stage and affects the same proportion of neurons in NGF and trkA mutants.
The situation is remarkably different for NT3 and trkC. Mutation of trkC is without effect on sympathetic ganglion cell numbers. NT3 mutants, on the other hand, show a reduction in sympathetic neuron numbers with the same time course as observed in NGF mutants. The data indicate that NT3 is required for sympathetic fibre outgrowth to the target tissues and access to NGF for survival. In DRG, both NT3 and trkC are required for cell survival at an earlier stage than NGF and trkA. With progressing development, cell death in NT3 mutants exceeds that in trkC mutants indicating a role for trkA in NT3 signal transduction. The time course of the NT3 effect indicates a requirement for DRG progenitors and differentiating neurons.

\section{Developmental course of differentiation effects}

Since rat DRG neurons lose their NGF dependence for survival rapidly after birth, NGF-mediated differentiation effects can be analysed in postnatal and adult animals after the manipulation of NGF levels (Fig. 3a). Electrophysiological analysis suggests a period of consolidation of LTMR (D hair) versus HTMR fates during early postnatal stages coincident with fibre rearrangement in the developing skin (Lewin and Mendell 1993). NGF deprivation appears to shift A $\delta$ HTMRs towards a D hair fate. In the $\mathrm{C}$ fibre domain, mechanoheat-sensitive units appear to be replaced by purely mechanosensitive afferents with an altered threshold. At later stages, phenotypic expression of specific properties remains subject to regulation by NGF (Mendell 1996). Altered neuropeptide and ion channel expression patterns in adult DRG neurons during inflammation are mediated in part by elevated NGF levels.

The introduction of the NT/Bax double-mutant mice has allowed NGF effects on differentiation to be analysed embryonically. This has established the NGF requirement for neuropeptide, ion channel and growth factor receptor expression in prenatal DRG neurons (Fig. 3b). Culture experiments indicate that the effects may occur directly on the ganglionic cell population.

For sympathetic neurons, the regulation of TH by NGF is shown from embryonic stages until adulthood. The analysis of other properties of sympathetic neurons is less complete and often restricted to cell culture.

Together, the data show that NT signalling, in particular that of NGF, might regulate neuronal properties at all developmental stages, uncorrelated with the survival requirement for NGF.

\section{NT effects on network differentiation and connectivity}

For the sensory neurons in DRG, the available data indicate that NT signalling affects a variety of differentiation events crucial for integrating the developing cells in their sensory 
Fig. 3 NGF effects on properties of DRG neurons are observed from embryogenesis to adulthood. a The different periods of NGF sensitivity in nociceptors and their precursors before and after birth. Modified from Lewin and Mendell 1993. b Embryonic effects of NGF on the expression of calcitoningene related peptide $(C G R P)$ and substance $\mathrm{P}(S P)$ in Bax/ trkA double-mutants and of ret, GFRalpha1, GFRalpha2, TRPV1 and TRPM8 in Bax/ NGF double-mutants in vivo and on neurons from Bax single mutants in vitro (\# number of positive cells/section)

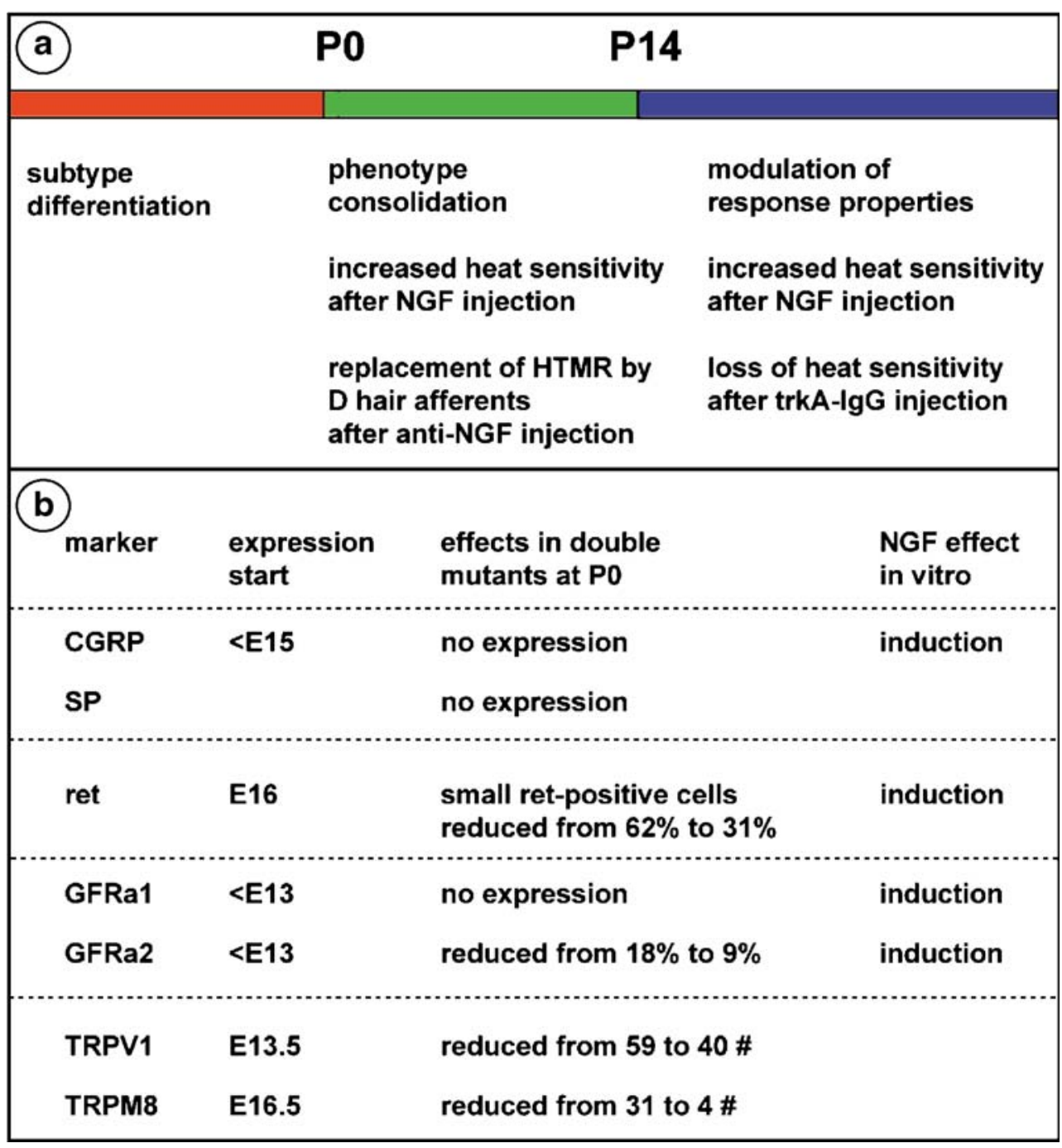

reflex networks. In the trkA-positive neuron population, NGF and trkA signalling is required for the expression of neuropeptides and GFL receptor subunits that specify peptidergic and non-peptidergic nociceptor populations, respectively. The expression of ion channels for the TRP family, which are involved in heat and cold sensation by small-diameter DRG neurons, is regulated by NGF/trkA signalling at embryonic stages and in adult animals. In addition, dorsal horn connectivity is affected by the modulation of NGF levels in postnatal animals. Thus, NGF/trkA signalling is essential for the molecular and functional specification of small-diameter DRG neurons and for their dorsal horn connectivity.

In the trkC-positive neuron population, the role of NT3 for the differentiation of proprioceptor properties is less well characterized. The importance of target-derived NT3 for the projection of proprioceptors to their targets in the ventral spinal cord and for functional transmission to motoneurons, however, demonstrates the potency of NT3/
trkC signalling for the shaping of the monosynaptic proprioceptor/motoneuron reflex pathway.

In sympathetic ganglia, NGF affects dendritic arborization and synapse development of postganglionic neurons and their connectivity with preganglionic neurons in vivo. These observations warrant further molecular characterization. Together with the in vivo data showing the requirement of NT3 and NGF for axonal projections and the in vitro results suggesting an effect of NGF on target innervation including synapse formation, the data indicate that NTs act as signals that regulate neuronal differentiation and the consequent integration into neural networks.

Signalling complexity

TH is regulated by NGF acutely via protein phosphorylation and in the long-term by protein synthesis. In sympathetic ganglia, the NGF-induced increase in specific $\mathrm{TH}$ activity is mediated by increased protein synthesis in 
parallel with increased mRNA amounts but, surprisingly, might be transcription-independent. Thus, posttranscriptional mechanisms appear active but these still have to be characterized. Moreover, TRP channel regulation by NGF in DRG occurs by both rapid and slow mechanisms. The acute activation also involves protein phosphorylation. The long-term regulation leads to increased mRNA levels that are assumed to be transcription-dependent, although posttranscriptional mechanisms cannot be excluded. Rapid NGF-dependent increases of heat-sensitivity in mature, but not postnatal, DRG neurons indicate that regulatory mechanisms may show different developmental availability.

Despite the subpopulation-specific action of NTs, several NTs might be involved in the development of a given neuron subpopulation. NT3 is required for the generation of approximately half of DRG and sympathetic neurons. In DRG, not only proprioceptors are lost in NT3 mutant mice, but also other sensory neuron populations (including peptidergic nociceptors) are reduced in numbers. This nociceptor population is reduced by $\sim 50 \%$ in NT3 mutant animals and appears to be completely eliminated by NGF mutation. The precise interplay of NGF and NT3 signalling in nociceptor development is not entirely clear. In sympathetic neurons, NT3 promotes early neurite outgrowth and NGF regulates later phases of neurite outgrowth, terminal branching and neuron survival. DRG and sympathetic neurons differ, however, in that cell loss attributable to the lack of NT3 appears as an indirect consequence of compromised access to NGF sources in the target region of sympathetic neurons, but not DRG. The molecular mechanisms underlying these differences and also the prolonged postnatal requirement of NGF for survival in sympathetic neurons as compared with DRG remain to be analysed.

Another example of NT interaction is found in SAM afferents, a population of LTMR. They require NT3 for survival and BDNF for acquisition of mechanosensitive properties. In the case of peptidergic nociceptors, NGF is required for both survival and the acquisition of characteristic neuronal properties. The molecular changes underlying the shift from survival promotion to phenotype specification by the same or different NTs still have to be determined.

In addition, NTs interact with other signalling systems. Both NT and bone morphogenetic protein signalling appear to be involved in dendrite formation of sympathetic neurons. trk and ret signalling is required for the development of non-peptidergic nociceptors in DRG. NGF signalling via trkA promotes ret expression in a subpopulation of DRG neurons. In sympathetic neurons, NGF stimulates ret expression and, different from DRG, ret phosphorylation (Tsui-Pierchala et al. 2002) adding another level of signalling complexity. Deciphering the interplay of growth factors in the regulation of the various aspects of neuronal development will be an important task for future research.
Acknowledgements I thank Frances Lefcort and Hermann Rohrer for critical reading of parts of the manuscript. Klaus Unsicker and Heinrich Betz are gratefully acknowledged for support. Ulla Hinz was very helpful with the collection of the articles cited.

Open Access This article is distributed under the terms of the Creative Commons Attribution Noncommercial License which permits any noncommercial use, distribution, and reproduction in any medium, provided the original author(s) and source are credited.

\section{References}

Agerman K, Hjerling-Leffler J, Blanchard MP, Scarfone E, Canlon B, Nosrat C, Ernfors P (2003) BDNF gene replacement reveals multiple mechanisms for establishing neurotrophin specificity during sensory nervous system development. Development 130:1479-1491

Aguayo LG, White G (1992) Effects of nerve growth factor on TTXand capsaicin-sensitivity in adult rat sensory neurons. Brain Res 570:61-67

Ai X, Cappuzzello J, Hall AK (1999) Activin and bone morphogenetic proteins induce calcitonin gene-related peptide in embryonic sensory neurons in vitro. Mol Cell Neurosci 14:506-518

Airaksinen MS, Meyer M (1996) Most classes of dorsal root ganglion neurons are severely depleted but not absent in mice lacking neurotrophin-3. Neuroscience 73:907-911

Albers KM, Wright DE, Davis BM (1994) Overexpression of nerve growth factor in epidermis of transgenic mice causes hypertrophy of the peripheral nervous system. J Neurosci 14:1422-1432

Albers KM, Perrone TN, Goodness TP, Jones ME, Green MA, Davis BM (1996) Cutaneous overexpression of NT-3 increases sensory and sympathetic neuron number and enhances touch dome and hair follicle innervation. J Cell Biol 134:487-497

Amaya F, Decosterd I, Samad TA, Plumpton C, Tate S, Mannion RJ, Costigan M, Woolf CJ (2000) Diversity of expression of the sensory neuron-specific TTX-resistant voltage-gated sodium ion channels SNS and SNS2. Mol Cell Neurosci 15:331-342

Amaya F, Shimosato G, Nagano M, Ueda M, Hashimoto S, Tanaka Y, Suzuki H, Tanaka M (2004) NGF and GDNF differentially regulate TRPV1 expression that contributes to development of inflammatory thermal hyperalgesia. Eur J Neurosci 20:23032310

Angeletti PU, Levi-Montalcini R, Caramia F (1971a) Analysis of the effects of the antiserum to the nerve growth factor in adult mice. Brain Res 27:343-355

Angeletti PU, Levi-Montalcini R, Caramia F (1971b) Ultrastructural changes in sympathetic neurons of newborn and adult mice treated with nerve growth factor. J Ultrastruct Res 36:24-36

Angeletti PU, Levi-Montalcini R, Kettler R, Thoenen H (1972) Comparative studies on the effect of the nerve growth factor on sympathetic ganglia and adrenal medulla in newborn rats. Brain Res 44:197-206

Arber S, Ladle DR, Lin JH, Frank E, Jessell TM (2000) ETS gene Er81 controls the formation of functional connections between group Ia sensory afferents and motor neurons. Cell 101:485-498

Arvanian VL, Mendell LM (2001) Removal of NMDA receptor $\operatorname{Mg}(2+)$ block extends the action of NT-3 on synaptic transmission in neonatal rat motoneurons. J Neurophysiol 86:123-129

Arvanian VL, Horner PJ, Gage FH, Mendell LM (2003) Chronic neurotrophin-3 strengthens synaptic connections to motoneurons in the neonatal rat. J Neurosci 23:8706-8712

Averill S, McMahon SB, Clary DO, Reichardt LF, Priestley JV (1995) Immunocytochemical localization of trkA receptors in chemically 
identified subgroups of adult rat sensory neurons. Eur J Neurosci 7:1484-1494

Babes A, Zorzon D, Reid G (2004) Two populations of cold-sensitive neurons in rat dorsal root ganglia and their modulation by nerve growth factor. Eur J Neurosci 20:2276-2282

Barbacid M (1994) The Trk family of neurotrophin receptors. J Neurobiol 25:1386-403

Benn SC, Costigan M, Tate S, Fitzgerald M, Woolf CJ (2001) Developmental expression of the TTX-resistant voltage-gated sodium channels Nav1.8 (SNS) and Nav1.9 (SNS2) in primary sensory neurons. J Neurosci 21:6077-6085

Bennett DL, Averill S, Clary DO, Priestley JV, McMahon SB (1996a) Postnatal changes in the expression of the trkA high-affinity NGF receptor in primary sensory neurons. Eur J Neurosci 8:22042208

Bennett DL, Dmietrieva N, Priestley JV, Clary D, McMahon SB (1996b) trkA, CGRP and IB4 expression in retrogradely labelled cutaneous and visceral primary sensory neurones in the rat. Neurosci Lett 206:33-36

Bennett DL, Koltzenburg M, Priestley JV, Shelton DL, McMahon SB (1998) Endogenous nerve growth factor regulates the sensitivity of nociceptors in the adult rat. Eur $\mathrm{J}$ Neurosci 10:1282-1291

Birren SJ, Lo L, Anderson DJ (1993) Sympathetic neuroblasts undergo a developmental switch in trophic dependence. Development 119:597-610

Bjerre B, Bjorklund A, Mobley W, Rosengren E (1975) Short- and long-term effects of nerve growth factor on the sympathetic nervous system in the adult mouse. Brain Res 94:263-277

Black IB, Hendry IA, Iversen LL (1972) Effects of surgical decentralization and nerve growth factor on the maturation of adrenergic neurons in a mouse sympathetic ganglion. J Neurochem 19:1367-1377

Black JA, Dib-Hajj S, McNabola K, Jeste S, Rizzo MA, Kocsis JD, Waxman SG (1996) Spinal sensory neurons express multiple sodium channel alpha-subunit mRNAs. Brain Res Mol Brain Res 43:117-131

Black JA, Langworthy K, Hinson AW, Dib-Hajj SD, Waxman SG (1997) NGF has opposing effects on $\mathrm{Na}^{+}$channel III and SNS gene expression in spinal sensory neurons. Neuroreport 8:23312335

Botchkarev VA, Botchkareva NV, Lommatzsch M, Peters EM, Lewin GR, Subramaniam A, Braun A, Renz H, Paus R (1998) BDNF overexpression induces differential increases among subsets of sympathetic innervation in murine back skin. Eur J Neurosci 10:3276-3283

Brodski C, Schnurch H, Dechant G (2000) Neurotrophin-3 promotes the cholinergic differentiation of sympathetic neurons. Proc Natl Acad Sci USA 97:9683-9688

Brodski C, Schaubmar A, Dechant G (2002) Opposing functions of GDNF and NGF in the development of cholinergic and noradrenergic sympathetic neurons. Mol Cell Neurosci 19:528538

Bron R, Klesse LJ, Shah K, Parada LF, Winter J (2003) Activation of Ras is necessary and sufficient for upregulation of vanilloid receptor type 1 in sensory neurons by neurotrophic factors. Mol Cell Neurosci 22:118-132

Burau K, Stenull I, Huber K, Misawa H, Berse B, Unsicker K, Ernsberger U (2004) c-ret regulates cholinergic properties in mouse sympathetic neurons: evidence from mutant mice. Eur J Neurosci 20:353-362

Carroll P, Lewin GR, Koltzenburg M, Toyka KV, Thoenen H (1998) A role for BDNF in mechanosensation. Nat Neurosci 1:42-46

Chen HH, Tourtellotte WG, Frank E (2002) Muscle spindle-derived neurotrophin 3 regulates synaptic connectivity between muscle sensory and motor neurons. J Neurosci 22:3512-3519
Coppola V, Kucera J, Palko ME, Martinez-De Velasco J, Lyons WE, Fritzsch B, Tessarollo L (2001) Dissection of NT3 functions in vivo by gene replacement strategy. Development 128:4315-4327 [Erratum in: Development (2003) 130:233]

Crowley C, Spencer SD, Nishimura MC, Chen KS, Pitts-Meek S, Armanini MP, Ling LH, McMahon SB, Shelton DL, Levinson $\mathrm{AD}$, et al (1994) Mice lacking nerve growth factor display perinatal loss of sensory and sympathetic neurons yet develop basal forebrain cholinergic neurons. Cell 76:1001-1011

D'Arcangelo G, Paradiso K, Shepherd D, Brehm P, Halegoua S, Mandel G (1993) Neuronal growth factor regulation of two different sodium channel types through distinct signal transduction pathways. J Cell Biol 122:915-921

Davies AM, Minichiello L, Klein R (1995) Developmental changes in NT3 signalling via TrkA and TrkB in embryonic neurons. EMBO J 14:4482-4489

Davis BM, Wang HS, Albers KM, Carlson SL, Goodness TP, McKinnon D (1996) Effects of NGF overexpression on anatomical and physiological properties of sympathetic postganglionic neurons. Brain Res 724:47-54

Dechant G, Rodríguez-Tébar A, Kolbeck R, Barde Y (1993) Specific high-affinity receptors for neurotrophin-3 on sympathetic neurons. J Neurosci 13:2610-2616

Dechant G, Rodríguez-Tébar A, Barde YA (1994) Neurotrophin receptors. Prog Neurobiol 42:347-352

Dhaka A, Viswanath V, Patapoutian A (2006) Trp ion channels and temperature sensation. Annu Rev Neurosci 29:135-161

Dib-Hajj SD, Black JA, Cummins TR, Kenney AM, Kocsis JD, Waxman SG (1998) Rescue of alpha-SNS sodium channel expression in small dorsal root ganglion neurons after axotomy by nerve growth factor in vivo. J Neurophysiol 79:2668-2676

DiCicco-Bloom E, Friedman WJ, Black IB (1993) NT-3 stimulates sympathetic neuroblast proliferation by promoting precursor survival. Neuron 11:1101-1111

Dixon JE, McKinnon D (1994) Expression of the trk gene family of neurotrophin receptors in prevertebral sympathetic ganglia. Brain Res Dev Brain Res 77:177-182

Djouhri L, Fang X, Okuse K, Wood JN, Berry CM, Lawson SN (2003) The TTX-resistant sodium channel Nav1.8 (SNS/PN3): expression and correlation with membrane properties in rat nociceptive primary afferent neurons. J Physiol (Lond) 550:739-752

Duc C, Barakat-Walter I, Philippe E, Droz B (1991) Substance P-likeimmunoreactive sensory neurons in dorsal root ganglia of the chick embryo: ontogenesis and influence of peripheral targets. Brain Res Dev Brain Res 59:209-219

Ehrhard PB, Otten U (1994) Postnatal ontogeny of the neurotrophin receptors trk and trkB mRNA in rat sensory and sympathetic ganglia. Neurosci Lett 166:207-210

ElShamy WM, Ernfors P (1996) A local action of neurotrophin-3 prevents the death of proliferating sensory neuron precursor cells. Neuron 16:963-972

ElShamy WM, Linnarsson S, Lee KF, Jaenisch R, Ernfors P (1996) Prenatal and postnatal requirements of NT-3 for sympathetic neuroblast survival and innervation of specific targets. Development 122:491-500

ElShamy WM, Fridvall LK, Ernfors P (1998) Growth arrest failure, G1 restriction point override, and $\mathrm{S}$ phase death of sensory precursor cells in the absence of neurotrophin-3. Neuron 21:1003-1015

Ernfors P, Merlio JP, Persson H (1992) Cells expressing mRNA for neurotrophins and their receptors during embryonic rat development. Eur J Neurosci 4:1140-1158

Ernfors P, Lee KF, Jaenisch R (1994a) Mice lacking brain-derived neurotrophic factor develop with sensory deficits. Nature 368:147-150 
Ernfors P, Lee KF, Kucera J, Jaenisch R (1994b) Lack of neurotrophin-3 leads to deficiencies in the peripheral nervous system and loss of limb proprioceptive afferents. Cell 77:503-512

Ernsberger U (2008) The role of GDNF family ligand signalling in the differentiation of sympathetic and dorsal root ganglion neurons. Cell Tissue Res 333:353-371

Ernsberger U, Rohrer H (1988) Neuronal precursor cells in chick dorsal root ganglia: differentiation and survival in vitro. Dev Biol $126: 420-432$

Fagan AM, Zhang H, Landis S, Smeyne RJ, Silos-Santiago I, Barbacid M (1996) TrkA, but not TrkC, receptors are essential for survival of sympathetic neurons in vivo. J Neurosci 16:62086218

Fang X, Djouhri L, Black JA, Dib-Hajj SD, Waxman SG, Lawson SN (2002) The presence and role of the tetrodotoxin-resistant sodium channel $\mathrm{Na}(\mathrm{v}) 1.9(\mathrm{NaN})$ in nociceptive primary afferent neurons. J Neurosci 22:7425-7433

Fang X, Djouhri L, McMullan S, Berry C, Okuse K, Waxman SG, Lawson SN (2005) trkA is expressed in nociceptive neurons and influences electrophysiological properties via Nav1.8 expression in rapidly conducting nociceptors. J Neurosci 25:4868-4878

Fang X, Djouhri L, McMullan S, Berry C, Waxman SG, Okuse K, Lawson SN (2006) Intense isolectin-B4 binding in rat dorsal root ganglion neurons distinguishes $\mathrm{C}$-fiber nociceptors with broad action potentials and high Nav1.9 expression. J Neurosci 26:7281-7292

Farinas I, Jones KR, Backus C, Wang XY, Reichardt LF (1994) Severe sensory and sympathetic deficits in mice lacking neurotrophin-3. Nature 369:658-661

Farinas I, Yoshida CK, Backus C, Reichardt LF (1996) Lack of neurotrophin-3 results in death of spinal sensory neurons and premature differentiation of their precursors. Neuron 17:10651078

Farinas I, Wilkinson GA, Backus C, Reichardt LF, Patapoutian A (1998) Characterization of neurotrophin and Trk receptor functions in developing sensory ganglia: direct NT-3 activation of TrkB neurons in vivo. Neuron 21:325-334

Fjell J, Cummins TR, Fried K, Black JA, Waxman SG (1999a) In vivo NGF deprivation reduces SNS expression and TTX-R sodium currents in IB4-negative DRG neurons. J Neurophysiol 81:803810

Fjell J, Cummins TR, Davis BM, Albers KM, Fried K, Waxman SG, Black JA (1999b) Sodium channel expression in NGFoverexpressing transgenic mice. J Neurosci Res 57:39-47

Fjell J, Cummins TR, Dib-Hajj SD, Fried K, Black JA, Waxman SG (1999c) Differential role of GDNF and NGF in the maintenance of two TTX-resistant sodium channels in adult DRG neurons. Brain Res Mol Brain Res 67:267-282

Ford CP, Wong KV, Lu VB, Posse de Chaves E, Smith PA (2008) Differential neurotrophic regulation of sodium and calcium channels in an adult sympathetic neuron. J Neurophysiol 99:1319-1332

Francis N, Farinas I, Brennan C, Rivas-Plata K, Backus C, Reichardt L, Landis S (1999) NT-3, like NGF, is required for survival of sympathetic neurons, but not their precursors. Dev Biol 210:411427

Galoyan SM, Petruska JC, Mendell LM (2003) Mechanisms of sensitization of the response of single dorsal root ganglion cells from adult rat to noxious heat. Eur J Neurosci 18:535-541

Garcia-Suarez O, Naves FJ, Del Valle ME, Esteban I, Bronzetti E, Vazquez E, Vega JA (1996) Distribution of p75 and trkneurotrophin receptor proteins in adult human sympathetic ganglia. Anat Embryol (Berl) 193:577-583

Gizang-Ginsberg E, Ziff EB (1990) Nerve growth factor regulates tyrosine hydroxylase gene transcription through a nucleoprotein complex that contains c-Fos. Genes Dev 4:477-491
Glebova NO, Ginty DD (2004) Heterogeneous requirement of NGF for sympathetic target innervation in vivo. J Neurosci 24:743751

Goedert M, Otten U, Thoenen H (1978) Biochemical effects of antibodies against nerve growth factor on developing and differentiated sympathetic ganglia. Brain Res 148:264-268

Goedert M, Otten U, Hunt SP, Bond A, Chapman D, Schlumpf M, Lichtensteiger W (1984) Biochemical and anatomical effects of antibodies against nerve growth factor on developing rat sensory ganglia. Proc Natl Acad Sci USA 81:1580-1584

Greene LA, Seeley PJ, Rukenstein A, DiPiazza M, Howard A (1984) Rapid activation of tyrosine hydroxylase in response to nerve growth factor. J Neurochem 42:1728-1734

Guidry G, Landis SC, Davis BM, Albers KM (1998) Overexpression of nerve growth factor in epidermis disrupts the distribution and properties of sympathetic innervation in footpads. J Comp Neurol 393:231-243

Guo A, Simone DA, Stone LS, Fairbanks CA, Wang J, Elde R (2001) Developmental shift of vanilloid receptor 1 (VR1) terminals into deeper regions of the superficial dorsal horn: correlation with a shift from TrkA to Ret expression by dorsal root ganglion neurons. Eur J Neurosci 14:293-304

Hall AK, Ai X, Hickman GE, MacPhedran SE, Nduaguba CO, Robertson CP (1997) The generation of neuronal heterogeneity in a rat sensory ganglion. J Neurosci 17:2775-2784

Hefti F, Gnahn H, Schwab ME, Thoenen H (1982) Induction of tyrosine hydroxylase by nerve growth factor and by elevated $\mathrm{K}^{+}$ concentrations in cultures of dissociated sympathetic neurons. $\mathrm{J}$ Neurosci 2:1554-1566

Hendry IA (1973) Trans-synaptic regulation of tyrosine hydroxylase activity in a developing mouse sympathetic ganglion: effects of nerve growth factor (NGF), NGF-antiserum and pempidine. Brain Res 56:313-320

Hendry IA (1975) The response of adrenergic neurones to axotomy and nerve growth factor. Brain Res 94:87-97

Hendry IA, Iversen LL (1971) Effect of nerve growth factor and its antiserum on tyrosine hydroxylase activity in mouse superior cervical sympathetic ganglion. Brain Res 29:159-162

Hill CE, Hendry IA, Ngu MC, Helden DF van (1985) Subpopulations of sympathetic neurones differ in their sensitivity to nerve growth factor antiserum. Brain Res 355:121-130

Hoheisel U, Unger T, Mense S (2007) Sensitization of rat dorsal horn neurons by NGF-induced subthreshold potentials and lowfrequency activation. A study employing intracellular recordings in vivo. Brain Res 1169:34-43

Hökfelt T, Kellerth JO, Nilsson G, Pernow B (1975) Substance P: localization in the central nervous system and in some primary sensory neurons. Science 190:889-890

Huang J, Zhang X, McNaughton PA (2006) Inflammatory pain: the cellular basis of heat hyperalgesia. Curr Neuropharmacol 4:197206

Iversen LL, Glowinski J, Axelrod J (1965) Reduced uptake of tritiated noradrenaline in tissues of immunosympathectomized animals. Nature 206:1222-1223

Jänig W, McLachlan EM (1992) Characteristics of function-specific pathways in the sympathetic nervous system. Trends Neurosci $15: 475-481$

Ji RR, Samad TA, Jin SX, Schmoll R, Woolf CJ (2002) p38 MAPK activation by NGF in primary sensory neurons after inflammation increases TRPV1 levels and maintains heat hyperalgesia. Neuron 36:57-68

Jia Z, Bei J, Rodat-Despoix L, Liu B, Jia Q, Delmas P, Zhang H (2008) NGF inhibits M/KCNQ currents and selectively alters neuronal excitability in subsets of sympathetic neurons depending on their $\mathrm{M} / \mathrm{KCNQ}$ current background. J Gen Physiol 131:575-587 
Johnson EM, Rich KM, Yip HK (1986) The role of NGF in sensory neurons in vivo. Trends Neurosci 9:33-37

Jones KR, Farinas I, Backus C, Reichardt LF (1994) Targeted disruption of the BDNF gene perturbs brain and sensory neuron development but not motor neuron development. Cell 76:989999

Jordt SE, McKemy DD, Julius D (2003) Lessons from peppers and peppermint: the molecular logic of thermosensation. Curr Opin Neurobiol 13:487-492

Josephson A, Widenfalk J, Trifunovski A, Widmer HR, Olson L, Spenger C (2001) GDNF and NGF family members and receptors in human fetal and adult spinal cord and dorsal root ganglia. J Comp Neurol 440:204-217

Ju G, Hökfelt T, Brodin E, Fahrenkrug J, Fischer JA, Frey P, Elde RP, Brown JC (1987) Primary sensory neurons of the rat showing calcitonin gene-related peptide immunoreactivity and their relation to substance P-, somatostatin-, galanin-, vasoactive intestinal polypeptide- and cholecystokinin-immunoreactive ganglion cells. Cell Tissue Res 247:417-431

Kahane N, Kalcheim C (1994) Expression of trkC receptor mRNA during development of the avian nervous system. J Neurobiol 25:571-584

Kalcheim C, Carmeli C, Rosenthal A (1992) Neurotrophin 3 is a mitogen for cultured neural crest cells. Proc Natl Acad Sci USA 89:1661-1665

Kashiba H, Senba E, Ueda Y, Tohyama M (1991) Cell size and cell type analysis of calcitonin gene-related peptide-containing cutaneous and splanchnic sensory neurons in the rat. Peptides 12:101-106

Kashiba H, Ueda Y, Senba E (1996) Coexpression of preprotachykininA, alpha-calcitonin gene-related peptide, somatostatin, and neurotrophin receptor family messenger RNAs in rat dorsal root ganglion neurons. Neuroscience 70:179-189

Kashiba H, Uchida Y, Senba E (2003) Distribution and colocalization of NGF and GDNF family ligand receptor mRNAs in dorsal root and nodose ganglion neurons of adult rats. Brain Res Mol Brain Res 110:52-62

Kessler JA, Black IB (1980a) The effects of nerve growth factor (NGF) and antiserum to NGF on the development of embryonic sympathetic neurons in vivo. Brain Res 189:157-168

Klein R (1994) Role of neurotrophins in mouse neuronal development. FASEB J 8:738-744

Klein R, Smeyne RJ, Wurst W, Long LK, Auerbach BA, Joyner AL, Barbacid M (1993) Targeted disruption of the trkB neurotrophin receptor gene results in nervous system lesions and neonatal death. Cell 75:113-122

Klein R, Silos-Santiago I, Smeyne RJ, Lira SA, Brambilla R, Bryant S, Zhang L, Snider WD, Barbacid M (1994) Disruption of the neurotrophin-3 receptor gene trkC eliminates la muscle afferents and results in abnormal movements. Nature 368:249-251

Klingman GI, Klingman JD (1967) Catecholamines in peripheral tissues of mice and cell counts of sympathetic ganglia after the prenatal and postnatal administration of the nerve growth factor antiserum. Int J Neuropharmacol 6:501-508

Kobayashi K, Fukuoka T, Obata K, Yamanaka H, Dai Y, Tokunaga A, Noguchi K (2005) Distinct expression of TRPM8, TRPA1, and TRPV1 mRNAs in rat primary afferent neurons with adelta/cfibers and colocalization with trk receptors. J Comp Neurol 493:596-606

Koltzenburg M, Bennett DL, Shelton DL, McMahon SB (1999) Neutralization of endogenous NGF prevents the sensitization of nociceptors supplying inflamed skin. Eur J Neurosci 11:1698-1704

Kornblum HI, Johnson EM Jr (1982) Time and dose dependencies of effects of nerve growth factor on sympathetic and sensory neurons in neonatal rats. Brain Res 234:41-51
Korsching S, Thoenen H (1983) Nerve growth factor in sympathetic ganglia and corresponding target organs of the rat: correlation with density of sympathetic innervation. Proc Natl Acad Sci USA 80:3513-3516

Korsching S, Thoenen H (1988) Developmental changes of nerve growth factor levels in sympathetic ganglia and their target organs. Dev Biol 126:40-46

Kramer I, Sigrist M, Nooij JC de, Taniuchi I, Jessell TM, Arber S (2006) A role for Runx transcription factor signaling in dorsal root ganglion sensory neuron diversification. Neuron 49:379-393

Krimm RF, Davis BM, Noel T, Albers KM (2006) Overexpression of neurotrophin 4 in skin enhances myelinated sensory endings but does not influence sensory neuron number. J Comp Neurol 498:455-465

Kucera J, Fan G, Jaenisch R, Linnarsson S, Ernfors P (1995) Dependence of developing group Ia afferents on neurotrophin3. J Comp Neurol 363:307-320

Kuruvilla R, Zweifel LS, Glebova NO, Lonze BE, Valdez G, Ye H, Ginty DD (2004) A neurotrophin signaling cascade coordinates sympathetic neuron development through differential control of TrkA trafficking and retrograde signaling. Cell 118:243-255

Lawson SN (2002) Phenotype and function of somatic primary afferent nociceptive neurones with C-, Adelta- or Aalpha/betafibres. Exp Physiol 87:239-244

Lawson SN, Crepps BA, Perl ER (1997) Relationship of substance P to afferent characteristics of dorsal root ganglion neurones in guinea-pig. J Physiol (Lond) 505:177-191

Lawson SN, Crepps B, Perl ER (2002) Calcitonin gene-related peptide immunoreactivity and afferent receptive properties of dorsal root ganglion neurones in guinea-pigs. J Physiol (Lond) 540:989-1002

Leah JD, Cameron AA, Snow PJ (1985) Neuropeptides in physiologically identified mammalian sensory neurones. Neurosci Lett 56:257-263

Lei S, Dryden WF, Smith PA (1997) Regulation of N- and L-type $\mathrm{Ca}^{2}$ ${ }^{+}$channels in adult frog sympathetic ganglion B cells by nerve growth factor in vitro and in vivo. J Neurophysiol 78:3359-3370

Lei S, Dryden WF, Smith PA (2001) Nerve growth factor regulates sodium but not potassium channel currents in sympathetic B neurons of adult bullfrogs. J Neurophysiol 86:641-650

Lein P, Johnson M, Guo X, Rueger D, Higgins D (1995) Osteogenic protein-1 induces dendritic growth in rat sympathetic neurons. Neuron 15:597-605

Leonard DG, Ziff EB, Greene LA (1987) Identification and characterization of mRNAs regulated by nerve growth factor in PC12 cells. Mol Cell Biol 7:3156-3167

Leslie TA, Emson PC, Dowd PM, Woolf CJ (1995) Nerve growth factor contributes to the up-regulation of growth-associated protein 43 and preprotachykinin A messenger RNAs in primary sensory neurons following peripheral inflammation. Neuroscience 67:753-761

Levi-Montalcini R, Booker B (1960a) Excessive growth of the sympathetic ganglia evoked by a protein isolated from mouse salivary glands. Proc Natl Acad Sci USA 46:373-384

Levi-Montalcini R, Booker B (1960b) Destruction of the sympathetic ganglia in mammals by an antiserum to a nerve-growth protein. Proc Natl Acad Sci USA 46:384-391

Levi-Montalcini R, Hamburger V (1951) Selective growth stimulating effects of mouse sarcoma on the sensory and sympathetic nervous system of the chick embryo. J Exp Zool 116:321-361

Lewin GR, Mendell LM (1993) Nerve growth factor and nociception. Trends Neurosci 16:353-359

Lewin GR, Mendell LM (1994) Regulation of cutaneous C-fiber heat nociceptors by nerve growth factor in the developing rat. $\mathrm{J}$ Neurophysiol 71:941-949

Lewin GR, Mendell LM (1996) Maintenance of modality-specific connections in the spinal cord after neonatal nerve growth factor deprivation. Eur J Neurosci 8:1677-1684 
Lewin GR, Lisney SJ, Mendell LM (1992) Neonatal Anti-NGF treatment reduces the Adelta- and $\mathrm{C}$-fibre evoked vasodilator responses in rat skin: evidence that nociceptor afferents mediate antidromic vasodilatation. Eur J Neurosci 4:12131218

Lewin GR, Ritter AM, Mendell LM (1993) Nerve growth factorinduced hyperalgesia in the neonatal and adult rat. J Neurosci $13: 2136-2148$

Li LY, Wang Z, Sedý J, Quazi R, Walro JM, Frank E, Kucera J (2006) Neurotrophin-3 ameliorates sensory-motor deficits in Er81deficient mice. Dev Dyn 235:3039-3050

Liebl DJ, Tessarollo L, Palko ME, Parada LF (1997) Absence of sensory neurons before target innervation in brain-derived neurotrophic factor-, neurotrophin 3-, and TrkC-deficient embryonic mice. J Neurosci 17:9113-9121

Liebl DJ, Klesse LJ, Tessarollo L, Wohlman T, Parada LF (2000) Loss of brain-derived neurotrophic factor-dependent neural crestderived sensory neurons in neurotrophin-4 mutant mice. Proc Natl Acad Sci USA 97:2297-2302

Liu X, Ernfors P, Wu H, Jaenisch R (1995) Sensory but not motor neuron deficits in mice lacking NT4 and BDNF. Nature 375:238241

Lockhart ST, Turrigiano GG, Birren SJ (1997) Nerve growth factor modulates synaptic transmission between sympathetic neurons and cardiac myocytes. J Neurosci 17:9573-9582

Lockhart ST, Mead JN, Pisano JM, Slonimsky JD, Birren SJ (2000) Nerve growth factor collaborates with myocyte-derived factors to promote development of presynaptic sites in cultured sympathetic neurons. J Neurobiol 42:460-476

Luo W, Wickramasinghe SR, Savitt JM, Griffin JW, Dawson TM, Ginty DD (2007) A hierarchical NGF signaling cascade controls Ret-dependent and Ret-independent events during development of nonpeptidergic DRG neurons. Neuron 54:739-754

Luther JA, Birren SJ (2006) Nerve growth factor decreases potassium currents and alters repetitive firing in rat sympathetic neurons. $\mathrm{J}$ Neurophysiol 96:946-958

Ma Y, Campenot RB, Miller FD (1992) Concentration-dependent regulation of neuronal gene expression by nerve growth factor. $\mathrm{J}$ Cell Biol 117:135-141

Mandel G, Cooperman SS, Maue RA, Goodman RH, Brehm P (1988) Selective induction of brain type II $\mathrm{Na}^{+}$channels by nerve growth factor. Proc Natl Acad Sci USA 85:924-928

Marti E, Gibson SJ, Polak JM, Facer P, Springall DR, Van Aswegen G, Aitchison M, Koltzenburg M (1987) Ontogeny of peptideand amine-containing neurones in motor, sensory, and autonomic regions of rat and human spinal cord, dorsal root ganglia, and rat skin. J Comp Neurol 266:332-359

Mathew TC, Miller FD (1990) Increased expression of T alpha 1 alpha-tubulin mRNA during collateral and NGF-induced sprouting of sympathetic neurons. Dev Biol 141:84-92

Max SR, Rohrer H, Otten U, Thoenen H (1978) Nerve growth factormediated induction of tyrosine hydroxylase in rat superior cervical ganglia in vitro. J Biol Chem 253:8013-8015

McCarthy PW, Lawson SN (1989) Cell type and conduction velocity of rat primary sensory neurons with substance P-like immunoreactivity. Neuroscience 28:745-753

McCarthy PW, Lawson SN (1990) Cell type and conduction velocity of rat primary sensory neurons with calcitonin gene-related peptide-like immunoreactivity. Neuroscience 34:623-632

McIlwrath SL, Hu J, Anirudhan G, Shin JB, Lewin GR (2005) The sensory mechanotransduction ion channel ASIC2 (acid sensitive ion channel 2) is regulated by neurotrophin availability. Neuroscience 131:499-511

McMahon SB, Jones NG (2004) Plasticity of pain signaling: role of neurotrophic factors exemplified by acid-induced pain. J Neurobiol 61:72-87
McMahon SB, Armanini MP, Ling LH, Phillips HS (1994) Expression and coexpression of Trk receptors in subpopulations of adult primary sensory neurons projecting to identified peripheral targets. Neuron 12:1161-1171

McTigue M, Cremins J, Halegoua S (1985) Nerve growth factor and other agents mediate phosphorylation and activation of tyrosine hydroxylase. A convergence of multiple kinase activities. J Biol Chem 260:9047-9056

Mendell LM (1996) Neurotrophins and sensory neurons: role in development, maintenance and injury. A thematic summary. Philos Trans R Soc Lond Biol 351:463-467

Mendelson B, Albers KM, Goodness TP, Davis BM (1996) Overexpression of nerve growth factor in epidermis of transgenic mice preserves excess sensory neurons but does not alter the somatotopic organization of cutaneous nerve projections. Neurosci Lett 211:68-72

Miller FD, Mathew TC, Toma JG (1991) Regulation of nerve growth factor receptor gene expression by nerve growth factor in the developing peripheral nervous system. J Cell Biol 112:303-312

Minichiello L, Piehl F, Vazquez E, Schimmang T, Hökfelt T, Represa J, Klein R (1995) Differential effects of combined trk receptor mutations on dorsal root ganglion and inner ear sensory neurons. Development 121:4067-4075

Minichiello L, Casagranda F, Tatche RS, Stucky CL, Postigo A, Lewin GR, Davies AM, Klein R (1998) Point mutation in trkB causes loss of NT4-dependent neurons without major effects on diverse BDNF responses. Neuron 21:335-345

Molliver DC, Snider WD (1997) Nerve growth factor receptor TrkA is down-regulated during postnatal development by a subset of dorsal root ganglion neurons. J Comp Neurol 381:428-438

Molliver DC, Wright DE, Leitner ML, Parsadanian AS, Doster K, Wen D, Yan Q, Snider WD (1997) IB4-binding DRG neurons switch from NGF to GDNF dependence in early postnatal life. Neuron 19:849-861

Moqrich A, Earley TJ, Watson J, Andahazy M, Backus C, MartinZanca D, Wright DE, Reichardt LF, Patapoutian A (2004) Expressing TrkC from the TrkA locus causes a subset of dorsal root ganglia neurons to switch fate. Nat Neurosci 7:812-818

Mu X, Silos-Santiago I, Carroll SL, Snider WD (1993) Neurotrophin receptor genes are expressed in distinct patterns in developing dorsal root ganglia. J Neurosci 13:4029-4041

Njå A, Purves D (1978) The effects of nerve growth factor and its antiserum on synapses in the superior cervical ganglion of the guinea-pig. J Physiol (Lond) 277:53-75

Obata K, Katsura H, Mizushima T, Yamanaka H, Kobayashi K, Dai Y, Fukuoka T, Tokunaga A, Tominaga M, Noguchi K (2005) TRPA1 induced in sensory neurons contributes to cold hyperalgesia after inflammation and nerve injury. J Clin Invest 115:2393-2401

Ogun-Muyiwa P, Helliwell R, McIntyre P, Winter J (1999) Glial cell line derived neurotrophic factor (GDNF) regulates VR1 and substance $P$ in cultured sensory neurons. Neuroreport 10:2107-2111

Ohtori S, Takahashi K, Chiba T, Yamagata M, Sameda H, Moriya H (2003) Calcitonin gene-related peptide immunoreactive neurons with dichotomizing axons projecting to the lumbar muscle and knee in rats. Eur Spine J 12:576-580

Olson L (1967) Outgrowth of sympathetic adrenergic neurons in mice treated with a nerve-growth factor (NGF). Z Zellforsch Mikrosk Anat 81:155-173

Omri G, Meiri H (1990) Characterization of sodium currents in mammalian sensory neurons cultured in serum-free defined medium with and without nerve growth factor. J Membr Biol 115:13-29

Orozco OE, Walus L, Sah DW, Pepinsky RB, Sanicola M (2001) GFRalpha3 is expressed predominantly in nociceptive sensory neurons. Eur J Neurosci 13:2177-2182 
Otten U, Schwab M, Gagnon C, Thoenen H (1977) Selective induction of tyrosine hydroxylase and dopamine betahydroxylase by nerve growth factor: comparison between adrenal medulla and sympathetic ganglia of adult and newborn rats. Brain Res 133:291-303

Otten U, Goedert M, Schwab M, Thibault J (1979) Immunization of adult rats against $2.5 \mathrm{~S}$ NGF: effects on the peripheral sympathetic nervous system. Brain Res 176:79-90

Patel TD, Jackman A, Rice FL, Kucera J, Snider WD (2000) Development of sensory neurons in the absence of NGF/TrkA signaling in vivo. Neuron 25:345-357 [Erratum in: Neuron (2003) 37:183]

Patel TD, Kramer I, Kucera J, Niederkofler V, Jessell TM, Arber S, Snider WD (2003) Peripheral NT3 signaling is required for ETS protein expression and central patterning of proprioceptive sensory afferents. Neuron 38:403-416

Patzke H, Ernsberger U (2000) Expression of neurexin Ialpha splice variants in sympathetic neurons: selective changes during differentiation and in response to neurotrophins. Mol Cell Neurosci 15:561-572

Pezet S, McMahon SB (2006) Neurotrophins: mediators and modulators of pain. Annu Rev Neurosci 29:507-538

Phillips HS, Armanini MP (1996) Expression of the trk family of neurotrophin receptors in developing and adult dorsal root ganglion neurons. Philos Trans R Soc Lond Biol 351:413-416

Price MP, Lewin GR, Mcllwrath SL, Cheng C, Xie J, Heppenstall PA, Stucky CL, Mannsfeldt AG, Brennan TJ, Drummond HA, Qiao J, Benson CJ, Tarr DE, Hrstka RF, Yang B, Williamson RA, Welsh MJ (2000) The mammalian sodium channel BNC1 is required for normal touch sensation. Nature 407:1007-1011 [Erratum in: Nature (2002) 418:352]

Raucher S, Dryer SE (1995) Target-derived factors regulate the expression of $\mathrm{Ca}^{2+}$-activated $\mathrm{K}^{+}$currents in developing chick sympathetic neurones. J Physiol (Lond) 486:605-614

Raynaud B, Faucon-Biguet N, Vidal S, Mallet J, Weber MJ (1988) Regulation of neurotransmitter metabolic enzymes and tyrosine hydroxylase mRNA level by nerve growth factor in cultured sympathetic neurones. Development 102:361-368

Rifkin JT, Todd VJ, Anderson LW, Lefcort F (2000) Dynamic expression of neurotrophin receptors during sensory neuron genesis and differentiation. Dev Biol 227:465-480

Ringstedt T, Kucera J, Lendahl U, Ernfors P, Ibáñez CF (1997) Limb proprioceptive deficits without neuronal loss in transgenic mice overexpressing neurotrophin-3 in the developing nervous system. Development 124:2603-2613

Rohrer H, Otten U, Thoenen H (1978) On the role of RNA synthesis in the selective induction of tyrosine hydroxylase by nerve growth factor. Brain Res 159:436-439

Rueff A, Mendell LM (1996) Nerve growth factor NT-5 induce increased thermal sensitivity of cutaneous nociceptors in vitro. $\mathrm{J}$ Neurophysiol 76:3593-3596

Ruit KG, Snider WD (1991) Administration or deprivation of nerve growth factor during development permanently alters neuronal geometry. J Comp Neurol 314:106-113

Ruit KG, Osborne PA, Schmidt RE, Johnson EM Jr, Snider WD (1990) Nerve growth factor regulates sympathetic ganglion cell morphology and survival in the adult mouse. J Neurosci 10:2412-2419

Ruit KG, Elliott JL, Osborne PA, Yan Q, Snider WD (1992) Selective dependence of mammalian dorsal root ganglion neurons on nerve growth factor during embryonic development. Neuron 8:573-587

Schecterson LC, Bothwell M (1992) Novel roles for neurotrophins are suggested by BDNF and NT-3 mRNA expression in developing neurons. Neuron 9:449-463

Schmidt RE, Dorsey DA, Selznick LA, DiStefano PS, Carroll SL, Beaudet LN, Roth KA (1998) Neurotrophin sensitivity of prevertebral and paravertebral rat sympathetic autonomic ganglia. J Neuropathol Exp Neurol 57:158-167

Seebach BS, Arvanov V, Mendell LM (1999) Effects of BDNF and NT-3 on development of Ia/motoneuron functional connectivity in neonatal rats. J Neurophysiol 81:2398-2405

Shadiack AM, Sun Y, Zigmond RE (2001) Nerve growth factor antiserum induces axotomy-like changes in neuropeptide expression in intact sympathetic and sensory neurons. J Neurosci 21:363-371

Silos-Santiago I, Molliver DC, Ozaki S, Smeyne RJ, Fagan AM, Barbacid M, Snider WD (1995) Non-TrkA-expressing small DRG neurons are lost in TrkA deficient mice. J Neurosci 15:5929-5942

Silos-Santiago I, Fagan AM, Garber M, Fritzsch B, Barbacid M (1997) Severe sensory deficits but normal CNS development in newborn mice lacking TrkB and TrkC tyrosine protein kinase receptors. Eur J Neurosci 9:2045-2056

Smeyne RJ, Klein R, Schnapp A, Long LK, Bryant S, Lewin A, Lira SA, Barbacid M (1994) Severe sensory and sympathetic neuropathies in mice carrying a disrupted $\mathrm{Trk} / \mathrm{NGF}$ receptor gene. Nature 368:246-249

Snider WD (1988) Nerve growth factor enhances dendritic arborization of sympathetic ganglion cells in developing mammals. J Neurosci 8:2628-2634

Snider WD (1994) Functions of the neurotrophins during nervous system development: what the knockouts are teaching us. Cell 77:627-638

Snider WD, Silos-Santiago I (1996) Dorsal root ganglion neurons require functional neurotrophin receptors for survival during development. Philos Trans R Soc Lond Biol 351:395-403

Stanke M, Duong CV, Pape M, Geissen M, Burbach G, Deller T, Gascan H, Otto C, Parlato R, Schutz G, Rohrer H (2006) Targetdependent specification of the neurotransmitter phenotype: cholinergic differentiation of sympathetic neurons is mediated in vivo by gp 130 signaling. Development 133:141-150

Stockel K, Solomon F, Paravicini U, Thoenen H (1974) Dissociation between effects of nerve growth factor on tyrosine hydrolase and tubulin synthesis in sympathetic ganglia. Nature 250:150-151

Story GM, Dicarlo SE, Rodenbaugh DW, Dluzen DE, Kucera J, Maron MB, Walro JM (2000) Inactivation of one copy of the mouse neurotrophin-3 gene induces cardiac sympathetic deficits. Physiol Genomics 2:129-136

Straub JA, Sholler GL, Nishi R (2007) Embryonic sympathoblasts transiently express TrkB in vivo and proliferate in response to brain-derived neurotrophic factor in vitro. BMC Dev Biol 7:10

Stucky CL, DeChiara T, Lindsay RM, Yancopoulos GD, Koltzenburg M (1998) Neurotrophin 4 is required for the survival of a subclass of hair follicle receptors. J Neurosci 18:7040-7046

Stucky CL, Shin JB, Lewin GR (2002a) Neurotrophin-4: a survival factor for adult sensory neurons. Curr Biol 12:1401-1404

Tate S, Benn S, Hick C, Trezise D, John V, Mannion RJ, Costigan M, Plumpton C, Grose D, Gladwell Z, Kendall G, Dale K, Bountra C, Woolf CJ (1998) Two sodium channels contribute to the TTX$\mathrm{R}$ sodium current in primary sensory neurons. Nat Neurosci 1:653-655

Tessarollo L, Tsoulfas P, Martin-Zanca D, Gilbert DJ, Jenkins NA, Copeland NG, Parada LF (1993) trkC, a receptor for neurotrophin-3, is widely expressed in the developing nervous system and in non-neuronal tissues. Development 118:463-475 [Erratum in: Development (1993) 118:1384]

Tessarollo L, Vogel KS, Palko ME, Reid SW, Parada LF (1994) Targeted mutation in the neurotrophin-3 gene results in loss of muscle sensory neurons. Proc Natl Acad Sci USA 91:11844-11848

Tessarollo L, Tsoulfas P, Donovan MJ, Palko ME, Blair-Flynn J, Hempstead BL, Parada LF (1997) Targeted deletion of all isoforms of the trkC gene suggests the use of alternate receptors 
by its ligand neurotrophin-3 in neuronal development and implicates trkC in normal cardiogenesis. Proc Natl Acad Sci USA 94:14776-14781

Thoenen H, Angeletti PU, Levi-Montalcini R, Kettler R (1971) Selective induction by nerve growth factor of tyrosine hydroxylase and dopamine-beta-hydroxylase in the rat superior cervical ganglia. Proc Natl Acad Sci USA 68:1598-1602

Thompson SW, Bennett DL, Kerr BJ, Bradbury EJ, McMahon SB (1999) Brain-derived neurotrophic factor is an endogenous modulator of nociceptive responses in the spinal cord. Proc Natl Acad Sci USA 96:7714-7718

Tojo H, Kaisho Y, Nakata M, Matsuoka K, Kitagawa M, Abe T, Takami K, Yamamoto M, Shino A, Igarashi K, et al (1995) Targeted disruption of the neurotrophin-3 gene with lacZ induces loss of trkC-positive neurons in sensory ganglia but not in spinal cords. Brain Res 669:163-175

Tonra JR, Mendell LM (1998) Effects of postnatal anti-NGF on the development of CGRP-IR neurons in the dorsal root ganglion. $\mathrm{J}$ Comp Neurol 392:489-498

Tsui-Pierchala BA, Milbrandt J, Johnson EM Jr (2002) NGF utilizes c-Ret via a novel GFL-independent, inter-RTK signaling mechanism to maintain the trophic status of mature sympathetic neurons. Neuron 33:261-273

Verge VM, Richardson PM, Wiesenfeld-Hallin Z, Hökfelt T (1995) Differential influence of nerve growth factor on neuropeptide expression in vivo: a novel role in peptide suppression in adult sensory neurons. J Neurosci 15:2081-2096

Vogt M (1964) Sources of noradrenaline in the immunsympathectomized rat. Nature 204:1315-1316

Wang Z, Li LY, Taylor MD, Wright DE, Frank E (2007) Prenatal exposure to elevated NT3 disrupts synaptic selectivity in the spinal cord. J Neurosci 27:3686-3694

Wetmore C, Olson L (1995) Neuronal and nonneuronal expression of neurotrophins and their receptors in sensory and sympathetic ganglia suggest new intercellular trophic interactions. J Comp Neurol 353:143-159

White FA, Silos-Santiago I, Molliver DC, Nishimura M, Phillips H, Barbacid M, Snider WD (1996) Synchronous onset of NGF and TrkA survival dependence in developing dorsal root ganglia. J Neurosci 16:4662-4672

Winston J, Toma H, Shenoy M, Pasricha PJ (2001) Nerve growth factor regulates VR-1 mRNA levels in cultures of adult dorsal root ganglion neurons. Pain 89:181-186
Woolf CJ (1996) Phenotypic modification of primary sensory neurons: the role of nerve growth factor in the production of persistent pain. Philos Trans R Soc Lond Biol 351:441-448

Woolf CJ, Costigan M (1999) Transcriptional and posttranslational plasticity and the generation of inflammatory pain. Proc Natl Acad Sci USA 96:7723-7730

Woolf CJ, Ma Q (2007) Nociceptors-noxious stimulus detectors. Neuron 55:353-364

Wright DE, Snider WD (1995) Neurotrophin receptor mRNA expression defines distinct populations of neurons in rat dorsal root ganglia. J Comp Neurol 351:329-338

Wright DE, Zhou L, Kucera J, Snider WD (1997) Introduction of a neurotrophin-3 transgene into muscle selectively rescues proprioceptive neurons in mice lacking endogenous neurotrophin-3. Neuron 19:503-517

Wyatt S, Pinon LG, Ernfors P, Davies AM (1997) Sympathetic neuron survival and TrkA expression in NT3-deficient mouse embryos. EMBO J 16:3115-3123

Wyatt S, Middleton G, Doxakis E, Davies AM (1999) Selective regulation of trkC expression by NT3 in the developing peripheral nervous system. J Neurosci 19:6559-6570

Zaimis E, Berk L, Callingham BA (1965) Morphological, biochemical and functional changes in the sympathetic nervous system of rats treated with nerve growth factor-antiserum. Nature 206:1220-1222

Zhang D, Yao L, Bernd P (1994) Expression of trk and neurotrophin mRNA in dorsal root and sympathetic ganglia of the quail during development. J Neurobiol 25:1517-1532

Zhang L, Schmidt RE, Yan Q, Snider WD (1994b) NGF and NT-3 have differing effects on the growth of dorsal root axons in developing mammalian spinal cord. J Neurosci 14:5187-5201

Zhang X, Huang J, McNaughton PA (2005) NGF rapidly increases membrane expression of TRPV1 heat-gated ion channels. EMBO J 24:4211-4223

Zhou XF, Chie ET, Deng YS, Rush RA (1997) Rat mature sympathetic neurones derive neurotrophin 3 from peripheral effector tissues. Eur J Neurosci 9:2753-2764

Zhu W, Galoyan SM, Petruska JC, Oxford GS, Mendell LM (2004) A developmental switch in acute sensitization of small dorsal root ganglion (DRG) neurons to capsaicin or noxious heating by NGF. J Neurophysiol 92:3148-3152

Zimmermann K, Leffler A, Babes A, Cendan CM, Carr RW, Kobayashi J, Nau C, Wood JN, Reeh PW (2007) Sensory neuron sodium channel Nav1.8 is essential for pain at low temperatures. Nature 447:855-858 